
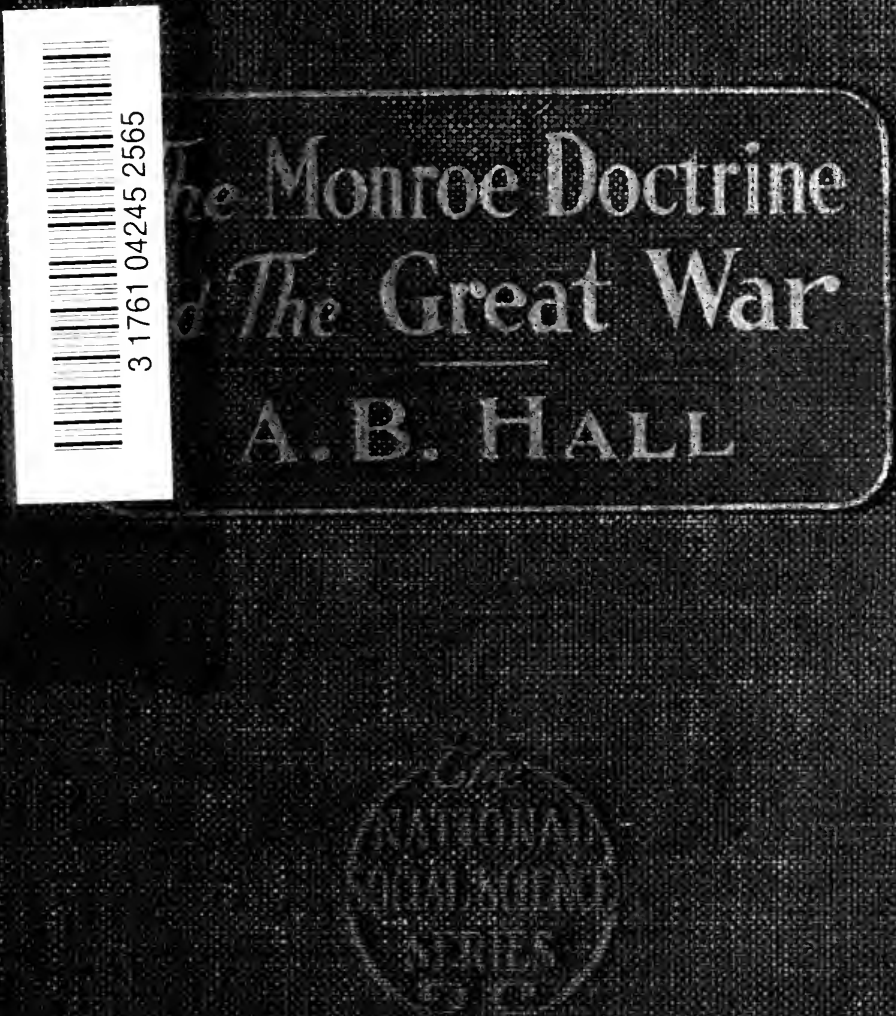


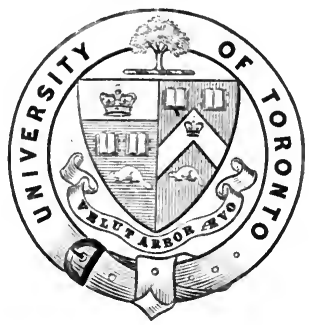

Dresented to

\section{The $\mathfrak{I}$ ibrary \\ of tbe}

\section{University of Toronto}

by

W. Stewart Wallace. req. 

Digitized by the Internet Archive in 2007 with funding from Microsoft Corporation 


\section{The National Social Science Series}

Edited by Frank L. McVey, Ph.D., LL.D., President of the University of Kentucky

\section{Now Ready: Each, Seventy-five Cents Net}

PROPERTY AND SOCIETY. A. R. BRUCE, Associate Justice Supreme Court, North Dakota.

WOMEN WORKERS AND SOCIETY. ANNIE M. MacLean, Assistant Professor of Sociology, The University of Chicago.

SOCIOlOGY. John M. Gilletre, Professor of Sociology, The University of North Dakota.

THE FAMILY AND SOCIETY. John M. Gilletre.

THE AMERICAN CITY. Henry C. Wright, First Deputy Commissioner, Department of Public Charities, New York City.

GOVERNMENT FINANCE IN THE UNITED STATES. Carl C. Plehn, Professor of Finance. The University of California.

THE COST OF LIVING. W. E. Clark, Professor of Political Science, The College of the City of New York. TRUSTS AND COMPETITION. JoHN F. CROWELL, Associate Editor of the Wall Street Journal.

MONEY. William A. Scotr, Professor of Political Economy, The University of Wisconsin.

BANKING. William A. Scotr.

TAXATion. C. B. Fillebrown, late President Massachusetts Single Tax League.

THE CAUSE AND CURE OF CRIME. Charles R. Henderson, late Professor of Sociology, The University of Chicago.

THE STATE AND GOVERNMENT. J. S. Young, Professor of Political Science, The University of Minnesota. 
SOCIAL ENVIRONMENT. George R. Davies, Assistant Professor in the Department of Economics, Princeton University.

National EVOlution. George R. Davies.

THE PSYCHOLOGY OF CITIZENSHIP. ARLaNd D. WeEks, Professor of Education, North Dakota Agricultural College.

SOCIAL ANTAGONISMS. ARLAND D. WeEKS.

statisticS. Wm. B. Bailey, Professor of Practical Philanthropy, Yale University, and JоHN Cummings, Expert Special Agent, Bureau of the Census.

WOMEN AND THE FRANCHISE. Josephine SchaIN, Executive Secretary, Association of Neighborhood Workers, New York City.

SOCIAL INSURANCE IN THE UNITED STATES. GURDON RANSOM Miller, Professor of Sociology and Economics, Colorado State Teachers' College.

HOUSING AND THE HOUSING PROBLEM. CARol AronovicI, Ph.D., Lecturer on Social Problems, University of Minnesota.

THE MONROE DOCTRINE AND THE GREAT WAR. ARNold Bennetr Hall, Associate Professor of Political Science, University of Wisconsin.

\section{In Preparation}

THE STRUGGLE FOR LAND IN AMERICA. Charles W. Holman, Expert of United States Industrial Commission.

SOCIAL AND ECONOMIC LEGISLATION. JEREMIAH S. YOUNG.

COOPERATION. L. D. H. WeLd, Professor of Business Administration, Yale University.

THE PUBLIC LIBRARY AS A SOCIAL FACTOR. W. D. Johnston, Librarian, St. Paul Public Library.

RURAL PROBLEMS IN THE UNITED STATES. JAMES E. BOYLE. 
I 


\title{
The Monroe Doctrine
}

\author{
AND
}

\section{THE GREAT WAR}

$\mathrm{BY}$

ARNold Bennett Hall, J.D.

Associate Professor of Political Science

University of Wisconsin

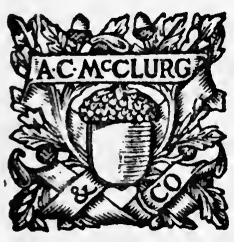

CHICAGO

A. C. McClURG \& CO. 
Copyright

A. C. McClurg \& Co. 1920

Published January, 1920

Copyrighted in Great Brtiain 


\section{To fty Parents}





\section{EDITOR'S PREFACE}

THERE is a close connection between the 1 Great War and the Monroe Doctrine. Our isolation from European difficulties is no longer a fact. We are a part of the world and compelled to carry a share of its burdens. This doctrine has been a great feature of American diplomatic history for a century. In the minds of many, a League of Nations means the giving up of this historic policy, but Professor Hall has shown that it is essentially akin to the policy laid down in the covenant.

As citizens we have talked a good deal about the Monroe Doctrine without really knowing what it means. In a hundred years new connotations have come into its phraseology and the duty of a citizen is to know what his country is holding out as a world policy. Professor Hall has added a readable, analytic book to the series that will help the American to get a wider view of our world policy.

$$
\text { F. L. M. }
$$


, 


\section{AUTHOR'S PREFACE}

WITH the victorious conclusion of the Spanish War America entered upon the rôle of a world power. While this new position of eminence was generally accepted by the American public, there is ample evidence that its fundamental implications were not popularly understood. The outbreak of the World War and its rapid sequence of events finally drove home to public consciousness the fact that the vital interests of our people were not restricted to the American continents.

With this understanding there followed the conviction that we could not be indifferent to the terms of peace, and it has become necessary, therefore, to formulate a foreign policy that will secure adequate protection to American interests in world affairs and at the same time give expression to American ideals. Any foreign policy that did not recognize these ideals could not receive the popular support necessary to become effective.

In times of international stress we have instinctively turned to the Monroe Doctrine as the basic principle of our foreign policy, and the present case is no exception. Any wise action that 
America may now take must be predicated upon an accurate understanding of this basic policy and its service to America and to the world.

To provide a means by which busy but thoughtful citizens may help themselves to grapple with this problem is the purpose of the author in the present book. His one aim has been to present in simple form an accurate but brief account of the origin and development of the doctrine and some of its relations to the present problems of peace. It is to be hoped that thus some aid may be given to the formation of an intelligent public opinion without which no foreign policy can possibly endure.

The author is glad to acknowledge the invaluable criticisms and suggestions of his colleagues, Professor F. A. Ogg and Mr. Graham H. Stuart, and finally the discriminating aid and counsel of his wife.

MADISON, WISCONSIN,

October 22, 1919.

Arnold Bennett Hall. 


\section{CONTENTS}

CHAPTER

PAGE

I The Foundations of the Monroe DOCTRINE . . . . . . I I

II Formulation of the Monroe DocTRINE • . . . . . I6

III Evolution of the Doctrine: I8231869 . $\quad \cdot \quad \cdot \quad \cdot \quad \cdot \quad \cdot \quad \cdot 35$

IV Evolution of the Doctrine: i869I9I8. • • . . . . $\quad$. 62

V The Pacific and the Far EAst . 82

VI Dollar Diplomacy and the CaribBEAN • • • .

VII ENForcement of the Doctrine • III VIII World War and the League of NaTIONS •

IX The Monroe Doctrine of the FuTURE • • • • • • • . I57 


\section{THE NATIONAL SOCIAL SCIENCE SERIES}

The purpose of this series is to furnish for busy men and women a brief but essentially sane and sound discussion of present-day questions. The authors have been chosen with care from men who are in first-hand contact with the materials, and who will bring to the reader the newest phases of the subject. 


\section{The Monroe Doctrine}

\section{CHAPTER I}

THE FOUNDATIONS OF THE MONROE DOCTRINE

THE erection of the thirteen jealous and bellig1 erent colonies into an effective and enduring union constituted the great triumph of American statecraft. With but few precepts or examples, its founders created this first great republican state, which was to work out its national destiny in the primitive forests of the New World and apparently far removed from the dynastic jealousies of the Old. With the domestic questions that confronted the young democracy at the very threshold of its existence we are not here concerned. Difficult and dangerous as they were, they were no more fundamental to the permanence of the nation than were the diplomatic problems confronting the new republic. With less than four million inhabitants scattered over an area of 892,000 square miles, without army or navy, threatened by hostile Indians, bounded by the colonial possessions of Spain on 
the south and west, by British territory on the north, with Russia holding territory in the Far Northwest, and France established in the West Indies, the new nation had to battle its way again overwhelming odds. Spain had never looked witi favor upon the American Revolution, and slic viewed the establishment of popular government in! proximity to her colonies as extremely dangero" :s to her colonial empire. There was also the adc :tional danger that the American colonies wou become the helpless pawns of European intrigue involved in European efforts to maintain the $B_{\boldsymbol{c}}$. ance of Power.

As early as 1782 John Adams foresaw these da?gers. In'a conversation with a British peace cornmissioner, he declared it to be clear that,

- . . all the powers of Europe will be continually manoeuvering with us, to work us into their real or imaginary Balance of Power. They will all wish to make of us a make-weight candle, when they are weighing out their pounds. Indeed, it is not surprising; for we shall very often, if not always, able to turn the scale. But I think it ought to our rule not to meddle; and that of all the powers Europe, not to desire us or, perhaps, even to pernit us to interfere, if they can help it.

Subsequent events showed how well founded was the fear, while the evils of becoming thus entangl with the wars and rivalries of Europe were obvious. 
The future of the new democracy, weak and helpless as it was, depended upon its enjoying a period of peace and security, in which it could develop power and lay the political and economic foundations of national strength and vigor.

The formulation of a foreign policy that would command the respect of powerful nations, avoid entanglements with European empires while securing their amity and friendship, eventually provide an outlet for the resistless spirit of expansion, and secure the territorial domain necessary for the home of the mighty nation, was the task that fell to the sagacious and far-seeing statesmanship of Washington and his cabinet.

The Doctrine of Isolation otherwise known as the "Doctrine of the Two Spheres," had already occurred to colonial statesmen as a common-sense method of avoiding the dangers of Old World entanglements. This doctrine sought to make the Atlantic an effective barrier between the politics of the two spheres in order that the peace and progress of America would not be contingent upon the political vicissitudes of Europe. In $178 \mathrm{I}$ Thomas Pownall in laying down the fundamental political principles of the "Empire of the United States" observed that,

As nature hath separated her from Europe, and hath established her alone (as a Sovereign) on a continent, far removed from the Old World and all its embroiled 
interests, it is contrary to the nature of her existence, and consequently to her interest, that she should have any connexions of politics with Europe other than merely commercial.

With characteristic vision Washington foresaw the practical value of the doctrine, and in January, I788, he wrote to Jefferson that,

The American Revolution has spread through Europe a better knowledge of the rights of mankind, the privileges of the people, and the principles of liberty than has existed in any former period; a war in that quarter is likely to be kindled, especially between France and England; in the impending struggle, an energetic general government must prevent the several states from involving themselves in the political disputes of European powers. The situation of the United States is such as makes it not only unnecessary but extremely imprudent for them to take part in foreign quarrels. Let them wisely and properly improve the advantages which nature has given them, and conduct themselves with circumspection. . .

It was but a brief interval before Washington was given an opportunity to meet the situation he had foreseen. The French Revolution, beginning in I789, brought about war with England in I793, and the revolutionary government of France submitted to America a proposed national agreement " in which two great peoples shall suspend their commercial and political interests and establish a mutual understanding to defend the empire of liberty, wherever 
it can be embraced." This proposal naturally made a tremendous appeal to the popular imagination, where the struggle for liberty had been so recent. Washington, keenly conscious of the weakness of his country, realizing fully the dangers of the proposed alliance, and supported by the more conservative people, who were aghast at the excesses of the Terror, stood firmly against the popular demand and sought to save to America the immense advantage of her isolation. This he did by adopting a policy of nonintervention and neutrality, thus refusing to be made a party to a European struggle. This step, dictated by the most obvious self-interest, established a permanent principle of foreign policy and gave to the world an advanced idea of the practice of neutrality which marked a new epoch in the development of international law.

So impressed was America's first president with the dangers of political alliances and with the advantages of preserving our isolation that he stressed it heavily in his famous Farewell Address, giving it an expression that has become classic:

The great rule of conduct for us in regard to foreign nations is, in extending our commercial relations, to have with them as little political connection, as possible. So far as we have already formed engagements, let them be fulfilled with perfect good faith. Here let us stop.

Europe has a set of primary interests which to us 
have none or a very remote relation. Hence she must be engaged in frequent controversies, the causes of which are essentially foreign to our concerns. Hence, therefore, it must be unwise in us to implicate ourselves by artificial ties in the ordinary vicissitudes of her politics or the ordinary combinations and collisions of her friendships or enmities.

Our detached and distant situation invites and enables us to pursue a different course. If we remain one people, under an efficient government, the period is not far off when we may defy material injury from external annoyance; when we may take such an attitude as will cause the neutrality we may at any time resolve upon to be scrupulously respected; when belligerent nations, under the impossibility of making acquisitions upon us, will not lightly hazard the giving us provocation; when we may choose peace or war, as our interest, guided by our justice, shall counsel.

Why forego the advantages of so peculiar a situation? Why quit our own to stand upon foreign ground? Why, by interweaving our destiny with that of any part of Europe, entangle our peace and prosperity in the toils of European ambition, rivalship, interest, or caprice?

Jefferson trenchantly summarized the idea when in his first inaugural address he declared for "Peace, commerce, and honest friendship with all nations, entangling alliances with none." Later, in his message of October 17,1803 , he declared:

Separated by a wide ocean from the nations of Europe and from the political interests which entangle them together, with productions and wants which ren- 
der our commerce and friendship useful to them and theirs to us, it cannot be the interest of any to assail us, nor ours to disturb them. We should be most unwise, indeed, were we to cast away the singular blessings of the position in which nature has placed us, the opportunity she has endowed us with of pursuing, at a distance from foreign contentions, the paths of industry, peace, and happiness, of cultivating general friendship, and of bringing collisions of interest to the umpirage of reason rather than of force.

In the meanwhile John Adams had given his endorsement to the policy of isolation in his special message of May 16, 1797:

Although it is very true that we ought not to involve ourselves in the political system of Europe, but to keep ourselves always distinct and separate from it if we can. . . . However we may consider ourselves, the maritime and commercial powers of the world will consider the United States of America as forming a weight in that Balance of Power in Europe which never can be forgotten or neglected. It would not only be against our interest, but it would be doing wrong to one-half of Europe at least, if we should voluntarily throw ourselves into either scale.

The revolutions of the Spanish American colonies from about 1806 down to their recognition by the United States in 1822 gave additional opportunities for further adherence to the policy of non-intervention and neutrality. Nor was this always easy to accomplish, since our republican sympathies were 
exploited and our pride quickened by the spectacle of this new struggle for independence by colonies who patterned their governments largely after ours. Thus the Doctrine of Isolation finding its expression in the policy of nonintervention and neutrality had become a definite part of our foreign policy by the time President Monroe gave it a new expression in his historic message.

In the meantime our statesmen had been extending the Doctrine of Isolation to the converse principle of nonintervention by European powers in American affairs. In view of the large American interests held by England, Spain, France, and Russia, the maintenance of this principle required a high degree of courage, imagination, and national self-reliance. While its development was somewhat later than the other aspects of the Doctrine of Isolation, it was foreshadowed by Hamilton in the Federalist when he predicted that,

By a steady adherence to the Union, we may hope, ere long, to become the arbiter of Europe in America, and to be able to incline the balance of European competitions in this part of the world as our interest may dictate.

The practical importance of this phase of our foreign policy did not strike home until the news of the cession of Louisiana by Spain to France in 1800 - to have the vast territory adjoining our 
southwestern boundaries pass from the possession of the declining empire of Spain into the stronger hands of France was a direct menace to the United States and might prove an effective barrier to her future expansion. It was on this occasion that Jefferson wrote his famous warning:

The cession of Louisiana and the Floridas by Spain to France works most sorely on the United States. It completely reverses all the political relations of the United States, and will form a new epoch in our political course. . . . There is on the globe one single spot, the possessor of which is our natural and habitual enemy. It is New Orleans. - . France, placing herself in that door, assumes to us the attitude of defiance. Spain might have retained it quietly for years. . .

He then proceeded to argue that an alliance with England and her navy would be imperative in order that the French settlements might be defeated and "for holding the two continents of America in sequestration for the common purposes of the United British and American nations." The feeling of our government was well illustrated by the conversation of Mr. King, United States minister to England, with Mr. Addington regarding New Orleans, when he declared:

We could not see with indifference that country in the hands of France, but it was equally true, that it would be contrary to our views, and with much con- 
cern, that we should see it in the possession of England; we had no objection to Spain continuing to possess it, they were quiet neighbors, and we looked forward without impatience to events which, in the ordinary course of things, must, at no distant day, annex this country to the United States.

However, the situation was not so critical as at first supposed, since the Treaty of San Ildefonso ceded only Louisiana and did not include the Floridas, as Jefferson was at first informed. The subsequent cession of Louisiana to the United States greatly simplified the problem of making effective America's policy against European interference. In I808 Jefferson in writing Governor Claiborne gave sweeping expression to this doctrine when he declared:

. . . we shall be well satisfied to see Cuba and Mexico remain in their present dependence; but very unwilling to see them in that of either France or England, politically or commercially. We consider their interests and ours as the same, and that the object of both must be to exclude all European influence from this hemisphere.

But the question of the Floridas still remained a menace on our southern border. A committee of the United States Senate declared:

If we look forward to the free use of the Mississippi, the Mobile, and the Apalachicola, and the other 
rivers of the West, by ourselves and our posterity, New Orleans and the Floridas must become a part of the United States, either by purchase or by con. quest;

and on January 3, I8I I, President Madison sent a secret message to Congress asking for authorization to occupy the Floridas in pursuance with an arrangement with the Spanish authorities, or without such arrangement if those authorities should be subverted and there should be danger of the occupancy of the territory by a foreign power. President Madison declared:

Taking into view the tenor of these several communications, the posture of things with which they are connected, the intimate relations of the country adjoining the United States eastward of the Perdido River to their security and tranquillity, and the peculiar interest they have in its destiny, I recommend to the consideration of Congress the seasonableness of a declaration that the United States could not see without serious inquietude, any part of a neighboring territory in which they have, in different respects, so deep and so just a concern pass from the hands of Spain into those of any other foreign power.

Congress acting in secret session granted the authority requested and reiterated the doctrine of Madison in a joint resolution to this effect:

that the United States, under the peculiar circumstances of the existing crisis, cannot, without 
serious inquietude, see any part of the said territory pass into the hands of any foreign power, and that a due regard to their own safety compels them to provide, under certain contingencies, for the temporary occupation of the said territory.

Thus an important part of our foreign policy was doubly secure by the sanction of congressional approval. The Floridas were finally purchased in 1819 and that source of danger removed, but the situation created by them and by the cession of Louisiana had called forth the definite formulation of America's policy to oppose to the uttermost any European interference with American affairs, which a few years later was courageously hurled against a formidable combination of European powers when President Monroe uttered his defiance to the American plans of the so-called "Holy Alliance."

From what has preceded it will appear that one of the most effective ways of avoiding European interference in America was the acquisition of territory held by foreign powers. Doubtless our success was in part due to the state of keen competition for colonial commerce among the nations of the Old World, which competition led them to consider it wiser to sell to America that which might otherwise fall into the hands of their competitors. While certain territory, such as New Orleans, was deemed valuable to the United States, the real cause of early expansion was undoubtedly the fear of 
European neighbors. Professor John Bassett Moore observes:

In reality, to the founders of the American republic, the question of territorial expansion did not present itself as a matter of speculation, or even of choice. There was not a single European power having possessions in America that did not lay claim to more territory than it had effectively occupied, nor was there a single one whose claims were not contested by some other power; and these contests were interwoven with the monopolistic struggle then in progress for colonial commerce and navigation. The Spaniards and the Portuguese, the English and the French, the Swedes and the Dutch, contended, with one another in Europe as well as in America for empire on the American continents. Their colonists knew no rule of life but that of conflict; and they regarded the extension of their boundaries as a measure of self-defense rather than of aggression.

This was doubtless the idea that animated Secretary Monroe's statement in his dispatch of December I0, I815:

The revolution which is making rapid progress in South America becomes daily more interesting to the United States. From the best information that we can obtain, there is much cause to believe, that those provinces will separate from the mother country. Several of them have already abrogated its authority, and established independent governments. They insist on the acknowledgment of their governments by the United States, and when it is considered that 
the alternative between governments, which in the event of their independence would be free and friendly, and the relation which, reasoning from the past, must be expected from them, as colonies, there is no cause to doubt in which scale our interest lies.

And it was this idea, together with the conviction that its interest in this hemisphere was paramount, that led the United States first to accord recognition to the Latin American republics. Also these were the same theories and convictions that caused the United States to seek escape from the present and future dangers of new European neighbors by opposing the effort of Russia to establish new colonies along the Pacific Coast.

When President Monroe was confronted with the hostile designs of the so-called "Holy Alliance" and the threat of the Russian ukase, he employed certain principles of established foreign policy that were immediately available for his needs. In the Doctrine of Isolation with its corollaries of American neutrality in respect to European interests and its insistence against European intervention in American affairs, supplemented as it was by our policy of expansion as a measure of self-protection, the president and his cabinet found already in existence some of the constituent elements of the famous doctrine. Their task was the reformulation and application of these principles to the problems at hand in such a manner as to preserve our present 
and future interests, and at the same time to divide the nations of Europe in order that we might not be opposed to the combined resources of European powers. This was certainly a task worthy of the best traditions of American diplomacy. 


\section{CHAPTER II}

FORMULATION OF THE MONROE DOCTRINE

PRIOR to the administration of President Monroe, America's consistent opposition to European interference in the political arrangements of the New World had not been aggressively challenged by any foreign power. Our theories of popular government had been viewed with suspicion and distrust, but no organized effort had been directed at their destruction. European powers had been too busy with the struggles of the Old World to devote much strength and energy to contesting their interests in the New. But with the defeat of Napoleon at Waterloo their energies were released for other fields of action. Under the pressure of the conflict, new international alliances had taken place and England, Russia, Prussia, and Austria, the nations which had defeated the "Man of Destiny," on November 20, I8I5, concluded a new treaty of alliance for the purpose of "safeguarding Europe from the dangers by which she may still be menaced."

This organization of states, commonly though inaccurately known as the "Holy Alliance," really 
originating in a treaty of March $\mathrm{I}, \mathrm{1} 8 \mathrm{i} 4$, established a union of the four powers, primarily for the successful prosecution of the war against Napoleon and secondarily to secure the future peace of Europe. This was renewed and made permanent by the treaty of alliance of March 25, 1815. The name of "Holy Alliance" was derived, not from the treaties that formed its basis, but from a document signed by Austria, Prussia, and Russia in Paris, September 26, 1815 , and that became the official cornerstone of the alliance. Alexander I, Czar of Russia, animated by an outburst of religious zeal following the downfall of Napoleon, took the initiative in the formulation of the document in which the three powers declared:

. . . their unwavering determination to adopt for the only rule of their conduct . . . . the precepts of their holy religion. . . . Considering themselves all as members of one great Christian nation, the three allied princes look upon themselves as delegates of Providence called upon to govern three branches of the same family, viz., Austria, Russia, and Prussia. . . . All those powers who wish solemnly to make avowal of the sacred principles which have dictated the present act . . . . shall be received . . . into this Holy Alliance.

It was this union of powerful European nations that was destined to put the courage and statesmanship of America to the acid test when it declared 
against the principles of democracy and proposed the reduction of the South American republics to the autocratic power of Spain.

While the alliance was called into existence by the common fear of Napoleon, the victory of Waterloo did not leave the European powers without a common cause. They were confronted with a new enemy against which their armies were destined to contend in vain, the growing spirit of democracy. Civilization stood aghast at the horrors and the bloodshed of the revolution. Anarchy in its boldest and most revolting form, masquerading in democratic garb had brought liberalism and popular government into temporary disrepute. The reaction towards absolutism seemed complete. The European alliance seized the strategic moment to consolidate their forces in defense of legitimacy and absolutism against the democratic dangers of the future. The first regular conference of the powers had been set for the year I8I8 at Aix-laChapelle. At this meeting France was admitted as a member of the alliance, and it was formally declared that they had, " no other object than the maintenance of peace, and the guarantee of those transactions on which the peace was founded and consolidated. . . . The reform of the world will be consistently their motive and their end." In spite of the apparent innocence of the declaration, England was not without misgivings. Canning, a 
member of the cabinet, was opposed to the whole alliance. He believed that it would become a source of cabal and intrigue, and that it was a dangerous policy to engage with despotic monarchs to determine when the public security would require intervention to suppress the revolutionary spirit. At this congress, American affairs were freely discussed and it was suggested that a representative of the Spanish royal family be sent to the New World to rule the Spanish colonies.

In 1820 a revolution broke out again in Spain, led by the army. "The liberal Constitution of 1812 was revived, and forced upon the reluctant king, and a new era seemed to open for the Spanish nation." This was followed by similar revolts against autocratic power in both Naples and Portugal, Alarmed by these popular revolts, the representatives of Austria, Russia, and Prussia met at Troppau in Octoher, I820, and later at Laybach where it was announced that the allies had

. . . taken the people of Europe into their holy keeping, and that in the future all useful and necessary changes in the legislation and administration of states must emanate alone from the free will, the reflected and enlightened impulse of those whom God has rendered responsible for power.

Under instructions from Laybach the Austrian army invaded southern Italy, suppressed the consti- 
tutional government and restored Ferdinand $\mathrm{I}$ to autocratic power. About the same time an insurrection broke out in Piedmont that was dealt with in the same summary and effective manner.

England was not officially represented at Troppau and Laybach and not only refused to join in the deliberations but protested against the principles enunciated in the Troppau circular. France, while participating in the conferences, refused to accede to the final act of intervention in Italy. Before adjournment at Laybach, arrangements were made for a meeting the following year to consider the affairs of Greece and Italy and more especially of Spain. In all three places the forces of absolutism were menaced by the growing spirit of popular revolt.

The Congress of Verona met in October, 1822. All of the five allies were present. The main issue before them was the proposed intervention in the affairs of Spain. Ferdinand vir was facing revolution at home and the loss of colonies abroad. One after another of the colonies was seeking to throw off the Spanish yoke. Its treasury empty, its army in rebellion, the Spanish Empire was facing ruin. Ferdinand vir appealed to the alliance to stamp out the revolution and to subjugate her colonies. Austria, Russia, and Prussia strongly favored intervention, France was uncertain, and England was opposed. Wellington, representing England, was 
under instructions to oppose the intervention, and finding opposition useless, he withdrew.

The result was a secret understanding that the French should suppress the Spanish Revolution. It was not without very serious domestic opposition that the French undertook the task, for the liberal party of Fran e was violently opposed. The war party finally triumphed and in April, 1823, France crossed the Bidassoa and by October had restored Ferdinand viI.

It was at this same Congress of Verona that the allies supplemented their preceding agreements with the secret treaty that formally pledged them against the cause of free government and the liberty of the press and to the defense of the doctrine of "Divine Right." In Article I it was agreed that,

The high contracting powers being convinced that the system of representative government is equally as incompatible with the monarchical principles as the maxim of the sovereignty of the people with the "Divine Right," engage mutually, in the most solemn manner, to use all their efforts to put an end to the system of representative governments, in whatever country it may exist in Europe, and to prevent its being introduced in those countries where it is not yet known.

\section{In Article II it was declared that,}

Since it cannot be doubted that the liberty of the press is the most powerful means used by the pre- 
tended supporters of the rights of nations, to the detriment of those of princes, the high contracting parties promise reciprocally to adopt all proper measures to suppress it, not only in their own states, but.also, in the rest of Europe.

The demand of Ferdinand vir for the subjugation of his American colonies received no definite action at this congress but plans were evolved the following year for another conference on American affairs; to which the United States was to be invited.

In the meanwhile American statesmen had been watching European developments with suspicious. eyes. The European alliance soon appeared to them in its true light as a menace to American isolation, to her policy against foreign intervention, and to the very existence of democracy itself. The motives, interests, and philosophy that would dictate intervention in Europe against the rising spirit of democracy, that would seek to resubjugate Spanish America to the arbitrary rule of Spain, might ultimately make common cause against the freedom of the United States. For the very existence of popular government was regarded as a menace to the power of despots, a constant reminder to their subjects of the possibilities of revolt.

The plans and purposes of the alliance as finally disclosed were diametrically opposed to the established foreign policy of the new republic as well as to its ideals and political convictions. As early 


\section{Formulation of the Monroe Doctrine 23}

as July, I8I8, President Monroe sought to forestall the situation by proposing to England a cooperation of the two governments to promote the independence of the Spanish American colonies, and from that time on the question of their independence was the subject of his continuous solicitude, and the separation of England from the allies his source of hope. In Niles Register of October I I, I8I7, is found a statement of the situation as it then appeared with an expressed wish for English cooperation which was practically fulfilled six years later.

It seems understood that some very important matters, in regard to Spain and her colonies, will occupy the attention of the next congress. In our own right and that of oppressed humanity, we might lawfully declare war against Spain, and no doubt should have declared it long since, if we had not been apprehensive of embroiling ourselves with the kings of other countries, united to defend one another against the people. But we trust that this unholy alliance may soon be broke; not because we wish war, but that every nation may freely regulate its own affairs - and as sovereigns, declare war and make peace, as to them shall seem just. And this event is certain - that if England would only balance the great European powers, the United States could easily throw in such a weight of strength and influence as immediately to destroy every vestige of Spanish supremacy on the American continent.

This prophetic and highly significant statement 
would seem to dispose of the contention frequently advanced that Canning was the author of the idea of cooperation in favor of Spanish America.

From time to time efforts were made to secure joint recognition of the independence of the Spanish colonies but to no avail. England, while convinced of their ultimate independence, was restrained by the fear of a breach and possible war with her continental allies. Finally in I 822 the United States began recognizing the independence of some of the stronger colonies. In thus taking the initiative her statesmen were expressing their conviction of their country's paramount interest in the Americas and their superior knowledge and understanding of American problems.

America's position was greatly simplified in I 822 by Canning's accession to the British Foreign Office. Canning was an able statesman, one who foresaw the future greatness of America and the advantages of a mutual understanding, who saw in the European alliance and its American plans a danger to British prestige and British trade. The success of France in putting down the Spanish Revolution and the possibility of he: acquiring an interest in Spanish America by way of indemnification for services rendered created a new problem for English statesmanship which Canning was quick to recognize. Moreover he realized that the secret treaty of Verona was a drastic instrument of 
absolutism for which no English Government could get support. It became his policy therefore to defeat the plans of the allies and prevent any of them, and particularly France, one of the strongest and most aggressive, from establishing their authority upon the Western Continent.

He thus found British interests to lie in the same direction as those of the United States. Consequently on August 16, I823, Canning sought an interview with Mr. Rush, the American minister, in which he suggested an informal agreement to oppose any interference by France or the other continental powers in American affairs. On August 22, Canning wrote a note to Rush of which the American minister gives us the following account:

$\mathrm{He}$ asks if the moment has not arrived when the two governments might understand each other as to the Spanish American colonies; and if so, whether it would not be expedient for ourselves, and beneficial for all the world, that our principles in regard to them should be clearly settled and avowed. That as to England she had no disguises on the subject.

(I) She conceived the recovery of the colonies by Spain to be hopeless.

(2) That the question of their recognition as independent states, was one of time and circumstances.

(3) That England was not disposed, however, to throw any impediment in the way of an arrangement between the colonies and the mother country, by amicable negotiations. 
(4) That she aimed at the possession of no portion of the colonies for herself.

(5) That she could not see the transfer of them to any other power with indifference.

That if the United States acceded to such views, a declaration to that effect, on their part, concurrently with England, would be the most effectual and least offensive mode of making known their joint disapprobation of contrary projects; that it would at the same time put an end to all the jealousies of Spain with respect to her remaining colonies, and to the agitation prevailing in the colonies themselves, by showing that England and the United States were determined not to profit by encouraging it.

Three days later Canning notified Rush of the proposal of the allies to call a conference on Spanish American affairs and urged again the matter of a joint declaration of their policy towards European interference. Rush replied with the suggestion that the British Government immediately recognize the independence of the Latin American states. Heretofore Rush had been unwilling to commit his government to the joint declaration without express authority, but he here suggested his readiness to assume responsibility for the declaration if England would agree to the policy of recognition. Mr. Rush declared:

My government would regard as alike objectionable, any interference whatever in the affairs of Spanish America, unsolicited by the late provinces themselves, 
and against their will; . . . . it would regard the convening of a congress to deliberate upon their affairs as a measure uncalled for, and indicative of a policy highly unfriendly to the tranquillity of the world; . . . . it could never look with insensibility upon such an exercise of European jurisdiction over communities now of right exempt from it, and entitled to regulate their own concerns unmolested from abroad.

Canning being unwilling to meet the condition no agreement was reached. Canning apparently lost interest for the time being but renewed the matter again in the latter half of September. This was due, as it was afterwards learned, to the unexpected assurances Canning had received from France that the latter government had no intention or desire to take advantage of the situation to secure any of the American colonies or to secure for herself , any exclusive advantages.

"The Rush-Canning correspondence was received in America in September, 1823, and created a profound impression. Great excitement prevailed. Many clamored for an alliance with England. President Monroe was very pessimistic and the cabinet was divided.

During this same period the dispute with Russia - was rapidly coming to an issue which was to add new complications to the tangle of diplomatic problems. In I82I the Russian Government had issued a ukase claiming the Pacific Coast as far south 
as the 5Ist degree, the north Pacific Ocean, and the Bering Sea. It furthermore issued a warning not to come within one hundred miles of the domain thus appropriated. The United States and England both denied the validity of the claim. In discussing it with the Russian minister, Baron von Tuyll, Adams "told him specially that we should contest the right of Russia to any territorial establishment on this continent, and that we should assume distinctly the principle that the American continents are no longer subjects for any new European colonial establishments." July 22, I823, he advised Middleton, the American minister to Russia that,

There can perhaps be no better time for saying, frankly and explicitly, to the Russian Government, that the future peace of the world, and the interest of Russia herself, cannot be promoted by Russian settlements upon any part of the American continent. With the exception of the British establishments north of the United States, the remainder of both the American continents must henceforth be left to the management of American hands. It cannot possibly be the purpose of Russia to form extensive colonial establishments in America. The new American republics will be as impatient of a Russian neighbor as the United States; and the claim of Russia to territorial possession, extending to the $5^{\text {Ist }}$ degree of north latitude, is equally incompatible with the British pretensions.

The Russian controversy was then still farther complicated by an announcement of Baron von 
Tuyll that Russia would "in nowise receive any agent . . . . of any of the de facto governments which owe their existence to the events of which the New World has for some years been the theater." Adams construed this as a suggestion that the United States might expect intervention in Spanish America. He replied with a statement of his country's policy of neutrality and declared that "if one or more of the European powers should depart from their neutrality, that change of circumstances would necessarily become a subject of further deliberation in this government, the result of which it was not in my power to foretell."

Confronted with this crisis President Monroe consulted the leading men of the country including ex-Presidents Jefferson and Madison regarding Canning's proposals. Jefferson's reply contained a statesmanlike summary of America's foreign policy and how he would apply it to the issues at hand:

The question presented by the letters you have sent me is the most momentous which has ever been offered to my contemplation since that of Independence. That made us a nation; this sets our compass and points the course which we are to steer through the ocean of time opening on us. And never could we embark on it under circumstances more auspicious. Our first and fundamental maxim should be, never to entangle ourselves in the broils of Europe. Our second, never to suffer Europe to intermeddle with cisatlantic affairs, America, North and South, has a set of in-

\section{t}


terests distinct from those of Europe and peculiarly her own. She should therefore have a system of her own, separate and apart from that of Europe. While the last is laboring to become the domicile of despotism, our endeavor should surely be to make our hemisphere that of freedom. One nation, most of all, could disturb us in this pursuit; she now offers to lead, aid, and accompany us in it. By acceding to her proposition we detach her from the band of despots, bring her mighty weight into the scale of free government, and emancipate a continent, at one stroke, which might otherwise linger long in doubt and difficulty. Great Britain is the nation which can do us the most harm of any one or all on earth, and with her on our side we need not fear the whole world. With her, then, we should most sedulously cherish a cordial friendship; and nothing would tend more to knit our affections than to be fighting once more, side by side, in the same cause. Not that I would purchase even her amity at the price of taking part in her wars. But the war in which the present proposition might engage us, should that be its consequence, is not her war, but ours. Its object is to introduce and establish the American system, of keeping out of our land all foreign powers, of never permitting those of Europe to intermeddle with the affairs of our nations. It is to maintain our own principle, not to depart from it. And if, to facilitate this, we can effect a division in the body of the European powers, and draw over to our side its most powerful member, surely we should do it. But I am clearly of Mr. Canning's opinion, that it will prevent instead of provoke war. With Great Britain withdrawn from their scale and shifted into that of our two continents, all Europe combined would not undertake such a war. 
Both ex-Presidents favored the policy of joint declaration with England.

Early in November, President Monroe began a series of consultations with his cabinet. Canning's proposal of a joint declaration had been approved by two great ex-Presidents, was favored by Rush and received the support of Calhoun and President Monroe. Adams opposed it. He alone appeared to have seen the self-denying character of the declaration that the British secretary would have imposed upon the United States.

The object of Canning appears to have been to obtain some public pledge from the government of the United States, ostensibly against the forcible interference of the Holy Alliance between Spain and South America; but really or specially against the acquisition to the United States themselves of any part of the Spanish American possessions.

Adams finally had his way and thus saved his country much subsequent embarrassment. His opposition to a joint declaration was finally placed upon the ground that the South Americans were independent nations, and as such they, and not England and America, "had the right to dispose of their condition."

Upon other matters the cabinet seemed unable to agree. About November 20, President Monroe laid before them the preliminary draft of his annual message which was to contain the declaration of 
America's policy. Among other things it contained a sharp attack upon France for interference in Spain, hostile criticism against the European alliance, and acknowledged the independence of the Greeks. In these last few days Adams set himself to the task of eliminating from the message all European matters except so far as they affected Spanish American affairs. He wanted the message to square with the traditional Doctrine of Isolation and to be essentially American. He urged:

That we should separate it from all European concerns, disclaim all intention of interfering with these, and make the stand altogether for an American cause: and that at the same time the answer to be given to the Russian communications shouid be used as the means of answering also the proposals of Mr. Gecrge Canning, and of assuming the attitude to be maintained by the United States with reference to the designs of the Holv Alliance upon South America.

On December 2, 1823, President Monroe in his annual message gave to the country and the world, America's answer to the contention of Russia, the threats of the European alliance and the proposals of Canning. This historic declaration of foreign policy known as the "Monroe Doctrine" is found in two separated passages, the following quotations from which contain the significant phrases:

(I) The American continents, by the free and ind pendent condition which they have assumed and main- 
tain, are henceforth not to be considered as subjects for future colonization by any European powers.

(2) In the wars of the European powers in matters relating to themselves we have never taken any part, nor does it comport with our policy so to do. It is only when our rights are invaded or seriously menaced that we resent injuries or make preparation for our defense.

(3) The political system of the allied powers is essentially different . . . . from that of America. This difference proceeds from that which exists in their respective governments. And to the defense of our own, which has been achieved by the loss of so much blood and treasure, and matured by the wisdom of their most enlightened citizens, and under which we have enjoyed unexampled felicity, this whole nation is devoted.

We owe it, therefore, to candor, and to the amicable relations existing between the United States and those powers, to declare that we should consider any attempt on their part to extend their system to any portion of this hemisphere as dangerous to our peace and safety.

(4) With the existing colonies or dependencies of any European power we have not interfered and shall not interfere. But with the governments who have declared their independence, and maintained it, and whose independence we have, on great consideration and on just principles, acknowledged, we could not view any interposition for the purpose of oppressing them, or controlling in any other manner their destiny, by any European power, in any other light than as the - manifestation of an unfriendly disposition towards the United States.'

(5) It is impossible that the allied powers should 
extend their political system to any portion of either American continent without endangering our peace and happiness; nor can anyone believe that our southern brethren, if left to themselves, would adopt it of their own accord. It is equally impossible, therefore, that we should behold such interposition, in any form, with indifference.

The doctrine was received with great enthusiasm in America. It expressed the aspirations of the new republic. It reaffirmed the established policies of the past and gave new confidence in their vitality and vigor for the future. While strenuously opposed in part by Canning and while its colonization features were declared "very extraordinary" and such as would meet with unequivocal opposition, the people of England accorded the doctrine in general their hearty praise. The European alliance knew that on the main issue the interests of America and England were the same. Against their united opposition, all hopes of intervention were abandoned. The freedom of the New World was saved from the despotism of the Old. America, untrammeled by self-denying treaties or entangling agreements stood forth triumphant and strong, confident in the consciousness of its new and larger destiny.

No war was necessary, no show of force; the moral effect of an understanding between the two great English-speaking nations was sufficient to maintain the equilibrium of a hemisphere - aye, of a world. 


\section{CHAPTER III}

EVOLUTION OF THE DOCTRINE: I823-I869

$7 \mathrm{HE}$ eloquent words of Webster describe the 1 profound effect created by Monroe's historic message.

One general glow of exultation, one universal feeling of the gratified love of liberty, one conscious and proud perception of the consideration which the country possessed, and of the respect and honor which belonged to it, pervaded all bosoms.

It gave a practical and articulate expression to the aspirations and ideals of the new republic; it paid a pleasing tribute to American wisdom and achievement, and it expressed a new sense of national importance and an increasing consciousness of national power. Moreover it was successful in achieving the ends toward which it was immediately directed. Von Gentz, the Austrian statesman, saw at once that the cause of the allies was hopeless.

The separation of America from Europe has been completed irrevocably. If the reconquest of the colonies on the continent or their voluntary return to the old rule had not already become impossible, this opposition of the North American people, which has 
so long been developed and which has only now been openly declared would alone be sufficient to banish all thoughts of it.

The British minister reported that the' message had confirmed Prince Metternich in his opinion "that great calamities would be brought upon Europe by the establishment of these vast republics in the New World, in addition to the power of the United States, of whose views no man could entertain a doubt after reading the speech in question. . . ." Not only were the plans of the European alliance thus defeated but the dispute with Russia was amicably and satisfactorily adjusted by the treaty of 1824 .

An analysis of the evidence shows that in the formulation of his doctrine, President Monroe and his cabinet took the established foreign policies as they found them, reformulated their expression to meet specific needs, and gave them utterance at a time and under conditions that secured the moral support of England. With remarkable skill they avoided any self-imposed restrictions that might embarrass or restrict their future. It was an achievement of constructive statesmanship worthy of the great nation in whose name they spoke.

The message restated the established "Doctrine of the Two Spheres" with its resulting argument against European intervention in the New World, correlated with the traditional policy of America to 
abstain from the policies of the Old. By substituting a unilateral declaration of policy for the British joint proposal they avoided an entangling alliance. with a European power, and left free the resistless spirit of expansion to work out its destiny unhindered by a self-denying clause. In declaring the policy of noninterference in European matters they took care to insert the exception that might arise "when our rights are invaded" in which case we would resent injuries or make preparations for defense. The reference to the extension of "their political system" to this continent was probably directed against the specific plans of the alliance rather than against the existence of monarchy in the Western World, and the paragraph on colonization was a mere declaration that American safety required that European nations regard our territorial status as finally determined.

The message did not guarantee western nations against disintegration or consolidation among themselves, nor against the territorial aggrandizement of the United States, nor did it seek to prohibit the transfer of American colonies from one European power to another although this principle had been twice suggested in 1803 and 1810 . It did not oppose "the existing rights or colonial possessions of any European power, but was a protest against the extension of their power and policy in the future." Furthermore it remains to be noticed that the doc.. 
trine was for the protection of American interests and not primarily for those of Latin America. In the words of A. B. Hart:

The Monroe Doctrine can be understood only as a statement of a right of self-protection against action by foreign powers. The main purpose of the doctrine was to prevent disturbances to our institutions, and to minimize dangers to the United States. Beyond this care for themselves, our grandfathers had a sincere and hearty desire and expectation that the Latin Americans would soon build up a better government than Spain had ever given them. In supporting their claims, in recognizing their independence, in standing for their security from interference, Monroe and other generous spirits felt that they were keeping alive the flame of liberty.

Popular as the message was, it did not receive, until the Venezuela controversy with England in I895, the sanction of congressional endorsement. Henry Clay, whose devotion to the cause of the Latin American republics was unceasing, sought to commit Congress to their defense. In January, I824, he offered in the House of Representatives a joint resolution to the effect that,

The people of these states would not see, without serious inquietude, any forcible intervention by the allied powers of Europe in behalf of Spain, to reduce to their former subjection those parts of the continent of America which have proclaimed and established for themselves, respectively, independent 
governments, and which have been solemnly recognized by the United States.

This resolution would have added a new and deeper significance to that portion of the Monroe Doctrine which it expressed, since it would have committed Congress, the war-making department of the government, to some definite action, if necessary, in defense of the new republics. Congress did not seem willing to commit itself and the matter was allowed to drop.

That the doctrine has afforded peace and protection to the United States seems amply vindicated. In the period from 1805 to 1823 civil wars in Latin America were incessant. The continuation of this struggle, aggravated by the additional forces of the European alliance and other possible examples of European interference, would have been a constant menace to the peace, happiness, and freedom of America. The effect on the European powers has been noted already, but the effect upon other potential schemes has perhaps been equally important. Only twice have hostile expeditions been directed against American states in opposition to the wishes of the United States and they were the expeditions against Santo Domingo and Mexico during the Civil War. Were it not for the Monroe Doctrine, wisely and bravely championed, who can tell what other like forces would now be operating on American 
territory and what limitations would today be imposed upon American diplomatic freedom by the presence of European powers firmly intrenched upon neighboring soil.

The discussion and application of the Monroe Doctrine during the period from 1823 to 1869 centers mainly around the Panama Congress of 1826 and the incidents relating to the Falkland Islands, Yucatan, Cuba, Panama, and Mexico.

John Quincy Adams, whose aggressive personality and commanding statesmanship had dominated the cabinet counsels of Monroe now came to the presidency. The project of the Pan-American Congress to be held at Panama in 1826 afforded him opportunity for the further discussion and application of the doctrine to which his genius had contributed so much. The idea of a general meeting of Latin American states began to develop in 1822 and in I824 took definite form under the leadership of General Bolivar. The following year the matter was broached to Clay, then Secretary of State, and finally a written invitation extended to the United States to join in the discussion of those matters

. . . which from their nature and importance, the late administration pointed out and characterized as being of general interest to the continent; for which reason, one of the subjects which will occupy the attention of the congress will be the resistance or opposition to the interference of any neutral nation in 
Evolution of the Doctrine: $1823-1869$ 4I

the question and war of independence between the new powers of the Continent and Spain.

Other matters, including those peculiarly and exclusively concerning the war still being waged against Spain, were also to be considered, but the United States was not expected to participate in the latter.

The purposes of the congress as published in South America and at that time unknown to the United States, were vastly different from the ones here suggested including the freeing of Cuba and the formation of a defensive league to unite in prosecuting war against the common enemy, Spain, "or against any other power, which shall assist Spain in her hostile designs, or otherwise assume the attitude of an enemy."

President Adams, eager to establish a policy of leadership among the American states and to support the cause of democracy in the New World, accepted the invitation. He was not however satisfied with the indefinite character of the statement of the purposes of the congress. In his first annual message, December 6, 1825 , he announced his acceptance of the invitation and in a special message of December 26, he sought to establish the interest of the United States in the conference.

The proposal met with bitter hostility and opposition in Congress which delayed for many weeks 
the necessary appropriation and the confirmation of the American delegates. The opposition was due partly to politics, partly to the President's lack of tact and partly to a fear of possible complications that might arise from such a conference. The objections were in the main that it was the formation of an entangling alliance contrary to the established policy of Washington, that the abolition of the slave trade would be considered, that the United States might be asked to support certain plans that would prejudice American designs on Cuba, and that they might be confronted with plans for international organization that would commit the United States to an intimate connection with the fortunes of the new republics that would be dangerous to her future interests.

Under the pressure of opposition Adams and Clay had to abandon their policy of strong American leadership and disclaim any proposed use of force or even strong diplomatic pressure in behalf of Latin America. Thus the Monroe Doctrine was not expanded but was toned down by the specific refusal to use force.

On account of the delay occasioned by congressional debate, the United States did not participate in the Conyress of Panama. Another meeting was arranged in Mexico the following year which was attended by American envoys but which came to naught through the failure of the other delegates 
to appear. This ended the project for a Pan-American congress and quieted public interest in Spanish America for the time being.

For almost twenty years following the Congress of Panama, the Monroe Doctrine was scarcely mentioned. The Latin American republics were left largely to themselves except for the continued diplomatic activity of adjusting claims against them for injuries to lives and property of foreigners. Wars, rebellions, military dictatorships passed in rapid succession. Law and order were practically unknown. Any hope of developing strong and effective governments seemed forlorn. During this period the question of European intervention in American affairs was raised by the British claim to the Malvinas or Falkland Islands. They were being used by American fishermen as ports of refuge when in 1829 Buenos Ayres took possession claiming them as a part of its republic. In I831 three American vessels were seized followed by the occupation of the islands by a United States vessel, the American minister to Buenos Ayres defending the rights of the fishermen. In the meantime Great Britain sent out a ship which took possession of the islands under a claim of title dating back for more than sixty years. Buenos Ayres contended that the British action was a flagrant breach of the Monroe Doctrine, but the United States acknowledged the validity of the British claim and the incident was 
closed. In later years Secretary Bayard declared that,

As the resumption of actual occupation of the Falkland Islands by Great Britain in I833 took place under a claim of title which had been previously asserted and maintained by that Government, it is not seen that the Monroe Doctrine, which has been invoked on the part of the Argentine Republic, has any application to the case.

On several minor occasions claims to the protection of the Monroe Doctrine were made by Latin American republics but to no avail. When England and France jointly blockaded the coast of the Argentine Republic to protect Uruguayan independence, appeals were made for American protection against the alleged violation of the doctrine, but without effect. Similar appeals were made with like results when England was noticeably extending her territorial claims in Nicaragua and Honduras. It was contended that "it had always been the policy of the United States to resist European settlements in America" but President Jackson declined to take a hand. The same indifference at Washington characterized the show of European force in American waters when France and Great Britain united to blockade the coast of Buenos Ayres in 1845.

In his annual message of December 2, I845, President Polk took occasion to restate rather fully 
the principles of the Monroe Dectrine with special emphasis upon the principle of colonization. $\mathrm{He}$ was the first president since Adams to hark back to the policies of Monroe. In them he sought to find authority for the policies of his administration and to use the doctrine as a warning against England's claims to Oregon. In his aggressive campaigns against Mexico for the acquisition of California he seemed partially to justify his policy on the theory that he would thus prevent this territory from passing to a European power. It scarcely would be said that such efforts added strength or dignity to his cause.

On April 29, 1848, in a special message favoring the annexation of the Mexican province of Yucatan, he again sought the authority of Monroe. The Indians and half-breeds of Yucatan had massacred many of the whites and apparently were seeking the extermination of that race on the peninsula. The whites petitioned the United States for aid offering to transfer to them the "dominion and sovereignty" of the province, and stating that similar appeals had been made to Spain and England. President Polk stated that while

. . . it is not my purpose to recommend the adoption of any measure, with a view to the acquisition of the "dominion and sovereignty" quer Yucatan, yet, according to our established policy, we could not consent to a transfer of this "dominion and sovereign- 
ty" to either Spain, Great Britain, or any other European power. In the language of President Monroe, in his message of December, 1823 , "we shall consider any attempt on their part to extend their system to any portion of this hemisphere as dangerous to our peace and safety." In my annual message of December, 1845 , I declared that "near a quarter of a century ago, the principle was distinctly announced to the world, in the annual message of one of my predecessors, that the 'American continents, by the free and independent condition which they have assumed and maintain, are henceforth not to be considered as subjects for future colonization by any European power." . . . This principle will apply with greatly increased force, should any European power attempt to establish any new colony in North America. In the existing circumstances of the world, the present is deemed a proper occasion to reiterate and reaffirm the principle avowed by Mr. Monroe, and to state my cordial concurrence in its wisdom and sound policy.

A bill for the military occupation of Yucatan was introduced into congress which gave rise to a spirited debate. Calhoun, a member of Monroe's cabinet took occasion to oppose bitterly Polk's extension of the doctrine. He declared that the colonization principle had never been discussed by the cabinet, that it was a contribution of Adams, and that it was an inaccurate statement of the facts of America at that time. Moreover he argued that the case at hand was not a case of "colonization" which means the establishment of a settlement, but 
that it was rather a case of "surrendered sovereignty" over a people already there. Yucatan would thus become a possession and not a colony, and therefore this was no occasion for the application of the policy. The protest against European intervention was inapplicable because it was a protest against the intervention of a hostile country to change the government and oppress the people, which was not the case before them. Finally the Monroe Doctrine contained no reference to resistance and the proposed extension was dangerous in that it placed in the hands of other governments on this continent the power to involve us in their wars.

The matter never came to a vote as information soon reached Congress that the matters in Yucatan had been amicably adjusted.

That the Monroe Doctrine was not regarded as a protection against territorial aggrandizement by the United States seems amply evidenced by the traditional desire for the acquisition of Cuba. After the Louisiana Purchase and the cession of Florida, Cuba was looked upon as a probable if not necessary addition to our territory. It was rich in resources, it commanded the approaches to the Gulf of Mexico and to a considerable portion of our national frontier, and finally its numerous ports could harbor fleets that might control the shipping that would develop in case of the building of the Isthmian Canal. 
Rumors occasionally arose that Cuba was about to be absorbed by some foreign nation and each time American statesmen declared that Cuba must not pass to another European power. In I840 it was rumored that Great Britain had designs on Cuba and Forsyth issued a clear and unequivocal statement of his country's policy.

Should you have reason to suspect any design on the part of Spain to transfer voluntarily her title to the island, whether of ownership or possession, and whether permanent or temporary, to Great Britain, or any other power, you will distinctly state that the United States will prevent it, at all hazards, as they will any foreign military occupation for any pretext whatsoever; and you are authorized to assure the Spanish Government that in case of any attempt from whatever quarter, to wrest from her this portion of her territory, she may securely depend upon the military and naval resources of the United States to aid her in preserving or recovering it.

The contest between the North and South over slave territory added additional interest to the question of the acquisition of Cuba. In 1848 President Polk sought to purchase the island but the only response was the assurance from Spain that "sooner than see the island transferred to any power, they would prefer seeing it sunk in the ocean." From I 849 to I 85 I three successive expeditions were fitted out in the United States under the command of Narcisso Lopez for the purpose of liberating Cuba. 
These filibustering expeditions, while not favored in the North, were popular in the slave-holding South. On account of these attempts England and France proposed a joint agreement with the United States, the first article providing that the three powers,

Hereby severally and collectively disclaim, both now and for hereafter, all intention to obtain possession of the island of Cuba ; and they respectively bind themselves to discountenance all attempt to that effect on the part of any power or individuals whatever. The high contracting parties declare, severally and collectively, that they will not obtain or maintain, for themselves or for any one of themselves, any exclusive control over the said island, nor assume nor exercise any dominion over the same.

Secretary Everett declined to adopt the proposed agreement stating that,

The policy of the United States has uniformly been to avoid as far as possible alliances or agreements with other states, and to keep itself free from national obligations, except such as affect directly the interests of the United States themselves.

The question of Cuba he conceived to be primarily an American question and the United States ought not to deny itself any future acquisition of territory in which it had so fundamental an interest.

The island of Cuba lies at our doors. It commands the approach to the Gulf of Mexico, which washes 
the shores of five of our States. It bars the entrance of that great river which drains half the North American continent, and with its tributaries forms the largest system of internal water communication in the world. It keeps watch at the doorway of our intercourse with California by the Isthmus route. If an island like Catba, belonging to the Spanish crown, guarded the cntrance of the Thames and the Seine, and the United States should propose a convention like this to France and England, those powers would assured-。 ly feel that the disability assumed by ourselves was far less serious than that which we asked them to assume.

In this remarkably able document Secretary Everett was not relying on Monroe alone but was developing a policy which later became known as the "Doctrine of Paramount Interest."

In I854 filibustering expeditions against Cuba began again, and the South, taking advantage of Cuban interference with American commerce, clamored for war. In the same year the three American ministers to Great Britain, France, and Spain, acting under instructions of the administration, met in consultation to consider the matter of the acquisition of Cuba. They issued a statement, known as the "Ostend Manifesto," setting forth the peculiar interest of America in Cuba. Several efforts to purchase the island in the years that followed met with no success. With the abolition of slavery in the United States the pressure for an- 
nexation was removed and the question of the acquisition of Cuba lost its diplomatic interest.

The controversy with England over the proposed Isthmian Canal, culminating in the Clayton-Bulwer Treaty, was a striking departure from the theory of paramount interest which was beginning to characterize the Monroe Doctrine, in admitting a European power as an equal partner in an American question. As early as 1825 our statesmen were taking an interest in the proposed canal and in 1835 the United States Senate requested the President to enter into negotiations to encourage such an undertaking and to secure the free navigation thereof. On December 12, I846, a treaty to this effect with New Granada was signed. By Article 35 the latter government guaranteed to the United States "the right of way or transit across the Isthmus of Panama upon any modes of commurication that now exist, or that may be hereafter constructed" and the United States guaranteed the perfect neutrality. of the Isthmus and the rights of sovereignty and property of New Granada over the territory of the same.

The acquisition of California in 1848 brought home to America with a new vividness the importance of the canal. In I849, Mr. Hise, American representative to Guatemala, negotiated a treaty with Nicaragua containing much the same provisions as referred to in the above treaty with New 
Granada. The treaty was negotiated and signed without authority and was never submitted to the Senate for ratification.

In the meanwhile England, an interested spectator of American efforts, was manipulating her claims in Central America in such a way as to monopolize the actual possibilities of a canal. England's interests in Central America began with the settlement of Belize, now British Honduras, to which there was a doubtful title and elastic boundaries. This had been followed up with a protectorate over the Mosquito Indians who had never acknowledged the sovereignty of the Central American republics, and whose capacity to make a binding treaty has never been admitted. Under color of enforcing a claim of the Mosquito Indians, the British captured in 1848 the strategic port of Greytown that was generally regarded as the necessary terminus of any trans-Isthmian enterprise within the territory of Nicaragua. In addition, Britain supported Costa Rica in claims to other territory of Nicaragua. Secretary of State Buchanan declared that "her purpose probably is to obtain control of the route for a railroad or canal between the Atlantic and Pacific oceans by way of Lake Nicaragua."

This seemed a clear case of a European power "oppressing" the Latin American republics "by controlling in any other manner their destiny" against which President Monroe had so boldly de- 
clared. Stephen A. Douglas and others sought to invoke the application of the Monroe Doctrine but without effect. Secretary Buchanan explained one of the embarrassments that would hamper such an effort.

To suffer any interference on the part of the European governments with the domestic concerns of the American republics, and to permit them to establish new colonies upon this continent, would be to jeopardize their independence and ruin their interests. These truths ought everywhere throughout this continent to be impressed upon the public mind; but what can the United States do to resist such European interferences whilst the Spanish American republics continue to weaken themselves by divisions and civil war, and deprive themselves of doing anything for their own protection.

The strong position occupied by Great Britain in Central America and the possibilities of her exclusive control of a canal alarmed the United States and interested her statesmen much more than did the mere violation of an established policy. To oust England by force was indeed a grave undertaking but one not necessary to the achievement of American aims, for their real interest lay in a free canal across the Isthmus not under the exclusive jurisdiction of any European nation.

With this aim in view negotiations were entered into with England which culminated in the Clayton- 
Bulwer Treaty. This agreement provided that any line of transit across any part of the Isthmus should be controlled jointly by the two powers and any European power that might care to join them and that the neutrality and free use of the canal would be jointly guaranteed. It was further agreed that neither party should assume or exercise dominion over any part of Central America. This treaty admitted England and other European powers as equal parties in a most important American problem contrary to the theory of our paramount interest in this hemisphere. It must be remembered however that the long-established intention of the United States was to secure the free use of an Isthmian Canal in which all nations might share and that at that time the Clayton-Bulwer Treaty seemed the best means to that end. It would moreover have removed English power from Central America had the former lived up to the spirit of the agreement.

Subsequently canal treaties were negotiated with Honduras in 1864, Nicaragua in 1868, and a new one with Colombia in 1867 , the latter failing of ratification in the Senate. In each of these undertakings the United States sought exclusive interests and their spirit cannot be reconciled with the intention of the Clayton-Bulwer Treaty.

Perhaps the clearest and most flagrant case of violating the Monroe Doctrine is found in the French intervention in Mexico. Here was an ob- 
vious attempt by a European power to extend the "political system" of Europe and to "control the destinies" of an American power. It does not appear to have been a mere accident that the attempt was made at a time when the United States, convulsed by civil war, was not able to oppose it to the uttermost, and there is ample reason to believe that similar incidents would have happened before but for fear of conflict with our established policy.

Our war with Mexico left that country in a condition of virtual anarchy in which dictator followed dictator. Life and property of foreigners were insecure and treaties were ignored. Rumors of a proposed European expedition into Mexico to collect debts and secure indemnity were heard in 1859. President Buchanan protested because of "our established policy, which is inconsistent with the intervention of any European power in the domestic concerns of that republic." Conditions became intolerable and France, Spain, and England united for joint intervention in Mexico in I86I to redress their grievances. They pledged each other

not to seek for themselves, in the employment of the coercive measures contemplated by the present convention, any acquisition of territory, nor any special advantage, and not to exercise in the internal affairs of Mexico any influence of a nature to prejudice the right of the Mexican nation to choose and to constitute freely the form of its government. 
The grievance of England was long-continued abuse of her subjects and representatives, culminating in the robbery of the British legation. France sought to collect payment on Mexican bonds held by her citizens and Spain complained of Mexico's refusal to abide by a treaty made with a rival faction.

The three nations joined in landing troops in Vera Cruz. It soon became apparent that France did not intend to keep her pledge and England and Spain withdrew. Emperor Napoleon instructed his commander in I86I that he might need to stay to give an opportunity to those Mexicans who might desire a strong and efficient government. In 1862 he declared his purpose "to establish bounds to the extension of the United States to the south, and to prevent her from controlling the commerce of the Gulf of Mexico." In the same year the city of Mexico was captured and Archduke Maximilian of Austria was made emperor of Mexico.

In 1860 when the intervention was rumored, Secretary of State Cass, while not denying the right to make war against Mexico for the redress of real grievances insisted "that such hostilities be fairly prosecuted for that purpose and be not converted into the means of acquisition or of political control." Later Secretary of State Seward, in declining an invitation to join the expedition declared that, 
The United States, so far as it is practicable, prefer to adhere to a traditional policy recommended to them by the Father of their Country and confirmed by a happy experience, which forbids them from making alliances with foreign nations; second, Mexico being a neighbor of the United States on this continent, and possessing a system of government similar to our own in many of its important features, the United States habitually cherish a decided good will towards that republic, and a lively interest in its security, prosperity and welfare.

With all the nation's energies engrossed in civil war and fearful of European recognition of the Confederacy, Seward postponed making an emphatic protest until after the battles of Gettysburg and Vicksburg. At no time, however, did he acquiesce in any improper intentions of the French, but rather indulged himself in the diplomatic fiction that none existed.

Feeling that the time had come for more positive action, the House of Representatives on April 4, 1864 , voted unanimously that,

The Congress of the United States are unwilling by silence to have the nations of the world under the impression that they are indifferent spectators of the deplorable events now transpiring in the republic of Mexico, and that they therefore think fit to declare that it does not accord with the policy of the United States to acknowledge any monarchial government erected on the ruins of any republican government in America under the auspices of any European power. 
But for the tact of Lincoln who declared that Congress was speaking on its own initiative and not for the administration, serious consequences might have followed.

At the close of the Civil War one hundred thousand American troops were sent down to the Mexican border and in November, 1865, Seward instructed Bigelow, the American minister to France to inform the French Government that the United States "still regard the effort to establish permanently a foreign and emporial government in Mexico as disallowable and impracticable." A year later Seward demanded that a time for the withdrawal of the French be determined and on April 6, I866, Napoleon III issued the proper orders. In this action it is clear that Napoleon III was actuated not only by the fear of American opposition but also by reason of the impending struggle between Austria and Prussia which might demand all of his energies in Europe.

In the correspondence regarding Mexico the words "Monroe Doctrine" appear only casually, if at all, although no reason appears for their omission unless it be Bigelow's advice from Europe to avoid using them because unpopular abroad. The same fundamental principles of American interest which underlay the Monroe Doctrine very obviously afforded the strength and logic that gave success to the diplomacy of Seward. 
During this period a few aspects of Monroe's message have been clarified. In the first place, the United States refused to commit itself to the general principle of the use of force against the violations of Latin America in connection with the Congress of Panama, Congress preferring the much wiser policy of meeting each situation on its individual merits, and being content with the President's general declaration of foreign policy. The failure of Adams to secure support for a strong program of American hegemony and the protection of Latin republics, together with the failure of the nation to respond to the many calls for help from the latter when suffering minor aggressions indicate that the Monroe Doctrine is considered primarily as a measure of self-defense and that the protection of Latin America is but an altruistic by-product.

The traditional attitude towards Cuba, the aggressive program of expansion, and Polk's attempt to justify territorial aggrandizement by appeals to the authority of Monroe, indicated a general feeling that the nation did not consider itself estopped by the Monroe Doctrine from expanding into neighboring territory. While Polk's effort to strengthen his policy of aggression by an appeal to the doctrine gained nothing in force or persuasion, it seems equally clear that it afforded him no embarrassment or difficulty though his conduct was in marked contrast to the altruistic expression of the doctrine. 
The 'Clayton-Bulwer Treaty in admitting England as an equal participant in an American problem was a departure from the Doctrine of Paramount Interest, but it was the only apparent means by which the canal could be assured without exclusive European control and that a British establishment in Central America could be prevented. It was a necessary choice between two evils rather than a voluntary departure from, established doctrines. Finally an addition seems to have been made to the policy of Monroe and that is that, in the words of President Grant, "no territory on this continent shall be regarded as subject of transfer to a European power." This had been suggested twice before Monroe's message and affirmed with such frequency and forcefulness since then, especially with reference to Cuba, that it may be safely said to have become an integral part of our established policy.

A survey of the period ending in 1869 shows that American statesmen had in the main adhered to the policy of safeguarding American interests against the dangers and problems of European politics by opposing any substantial efforts towards "Colonization by any European powers," by protecting the Latin American states against "any interposition for the purpose of oppressing them or controlling in any other manner their destiny," and by resisting any European effort to "extend their 
Evolution of the Doctrine: $1823-1869$ 6I

political system to any portion" of the New World. While there have been differences as to the doctrine's applicability to difficult situations there can be little doubt that America would have always regarded a palpable violation as an unfriendly act. As already observed this attitude of the United States not only prevented the execution of the plans of the European alliance and saved Mexico from the hands of France, but it has doubtless prevented other hostile expeditions and consequently has saved us from the dangers of powerful European neighbors that would have menaced and hampered the destiny of the United States. 


\section{CHAPTER IV}

EVOLUTION OF THE DOCTRINE: I869-I9I8

IN THE period just following the Civil War 1 questions of foreign politics were neglected, as the public became engrossed in the more immediate problems of reconstruction and western migration. The completion of trans-continental railroads obviated the immediate necessity of an Isthmian Canal, and for years American statesmen vainly tried to get popular support for foreign policies.

The Clayton-Bulwer Treaty still remained a selfdenying alliance with a European power. It had not facilitated the building of a canal and it stood as a constant challenge to the Doctrine of Paramount Interest. Secretary of State Fish, while not expressly objecting to the treaty with England, negotiated in 1870 a treaty with Colombia for sole American control. He declared that joint control would be a source of "future trouble" and that the "President is disinclined to enter into any entanglement in participation of control over the work" and that he regards it "as an American enterprise." The treaty failed of ratification in the Colombian Senate, however, and the United States thereupon 


\section{Evolution of the Doctrine: 1860-1918}

provided for an Interoceanic Canal Commission which in 1875 reported in favor of the Nicaraguan route.

In I879 a French company was formed to build an Isthmian Canal and in 1883 construction on a canal by the Panama route was begun. This brought the question of America's interest in the canal to the front. On March 8, 1880, Secretary of State Evarts reported that the United States was sincerely interested in securing the building of a canal to be used on equal terms by the commerce of the world, but that,

The paramount interest of the United States in these projects of interoceanic communication across the American Isthmus has seemed quite as indisputable to the European powers as to the States of this continent.

This was followed by a formal message by President Hayes developing with great lucidity America's claim to the supreme interest in the canal.

The policy of this country is a canal under American control. If there are obstacles in the way, they must be removed by just and liberal negotiations. The capital invested, by corporations or citizens of other countries in such an enterprise must, in a great degree, look for protection to one or more of the great powers of the world. No European power can intervene for such protection without adopting measures on this continent which the United States would deem wholly 
inadmissible. If the protection of the United States is relied upon, the United States must exercise such control as will enable this country to protect its national interests and maintain the rights of those whose private capital is embarked in the work.

An interoceanic canal across the American Isthmus will essentially change the geographical relations between the Atlantic and Pacific coasts of the United States, and between the United States and the rest of the world. It will be the great ocean thoroughfare between our Atlantic and our Pacific shores and virtually a part of the coast line of the United States. Our merely commercial interest in it is greater than that of all other countries, while its relations to our power and prosperity as a nation, to our means of defense, our unity, peace, and safety are matters of paramount concern to the people of the United States. No other great powers would, under similar circumstances, fail to assert a rightful control over a work so closely and vitally affecting its interest and welfare.

In I88r, President Garfield declared in his inaugural address that it was the "Right and duty of the United States to assert and maintain such supervision and authority over any interoceanic canal across the Isthmus . . . . as will protect our national interests." In June of the same year, Secretary of State Blaine developed the same idea in a circular dispatch and sought for it the authority of Monroe.

An agreement between the European states to jointly guarantee the neutrality and in effect control 
the political character of a highway of commerce, remote from them and near to us, forming substantially a part of our coast line and promising to become the chief means of transportation between our Atlantic and Pacific states, would be viewed by this government with the gravest concern. . . . Any attempt to supersede that guarantee by an agreement between European powers, which maintain vast armies and patrol the sea with immense fleets, and whose interest in the canal and its operations can never be so vital and supreme as ours, would partake of the nature of an alliance against the United States, and would be regarded by this government as an indication of unfriendly feeling.

It is the long-settled conviction of this government that any extension to our shores of the political system by which the great powers have controlled and determined events in Europe would be attended with danger to the peace and welfare of this nation. . . . It is nothing more than the pronounced adherence of the United States to principles long since enunciated by the highest authority of the government, and now, in the judgment of the President, firmly inwoven as an integral and important part of our national policy.

This message accurately forecast the policy ultimately executed by his government.

When the Clayton-Bulwer Treaty was called to his attention by England, Blaine then proposed to avoid its obligations on the ground that England had not observed it, that it had lapsed by change of circumstances and that it was unjust to American interests. He emphasized the British control 
of the Suez Canal and urged that it would be no more unreasonable for America to demand a share in the control of the Suez Canal than it was for England to insist upon her rights under the ClaytonBulwer agreement. Moreover he urged with great force the superior position of America for defending the canal in time of war. The Civil War had shown that the United States would be supreme in any military conflict on the American continents.

The one conclusive mode of preserving any Isthmus canal from the possible distraction and destruction of war is to place it under the control of that government least likely to be engaged in war, and able, in any and every event, to enforce the guardianship which she shall assume.

Lord Granville replied for Great Britain that the present circumstances were the result of forces evident at the time of the treaty and that they did not therefore alter it. Moreover Great Britain had large colonial and commercial interests in America, and the proposed canal concerned not only the United States, but the whole civilized world. From a purely legal standpoint Lord Granville had the best of the argument but he was unable to dispel the idea of America's dominance in canal interests.

Blaine's campaign was continued by his successor, Secretary Frelinghuysen, who declared that,

The President believes that the formation of a protectorate by European nations over the Isthmus tran- 
sit would be in conflict with a doctrine which has been for many years asserted by the United States.

President Cleveland, however, took an opposite tack, withdrawing the Zavala Treaty with Nicaragua (negotiated in 1884, but never ratified by the Senate) which gave to the United States a special advantage in a Nicaraguan route. He was strenuously opposed to expansion or the acquisition of any special territorial status, and while mildly in favor of the canal he observed that,

Whatever highway may be constructed across the barrier dividing the two greatest maritime areas of the world must be for the world's benefit - a trust for mankind, to be removed from the chance of domination by any single power.

President Harrison, however, in his inaugural address reasserted the doctrine of his predecessors. He called attention to America's policy "of avoiding all interference with European affairs" and declared that,

It is so manifestly incompatible with those precautions for our peace and safety, which all the great powers habitually observe and enforce in matters affecting them, that a shorter waterway between our eastern and western seaboards should be dominated by any European government, that we may confidently expect that such a purpose will not be entertained by any friendly power. 
The Spanish American War with its resulting acquisition of Pacific territory, the long voyage of the Oregon from San Francisco to Santiago in time of national peril, and the hopes for greatly increased trade with the Orient created a great popular interest in the canal. Condemnation of the ClaytonBulwer Treaty became popular. In his second annual message President McKinley announced himself in favor of an "American Canal." The annexation of the Hawaiian Islands and the prospective expansion in the Pacific make the canal more than ever indispensable.

That our national policy now more imperatively than ever calls for its control by this government, are propositions which I doubt not the Congress will duly appreciate and wisely act upon.

President McKinley's position apparently had the support of Congress and the public. Secretary Hay began negotiations in I900 which culminated in the Hay-Pauncefote Treaty by which the ClaytonBulwer Treaty was expressly revoked and the matter of the canal left to the United States. This was a triumph for our Doctrine of Paramount Interest in all things American. Our statesmen in putting it forward had referred back expressly or inferentially to the doctrine of Monroe. Doubtless the same fundamental principle was involved, the principle of self-defense. Monroe's opposition to 
European colonization, to the extension of the European political systems, and the control or oppression of American colonies was placed on the ground that it would endanger "our peace and happiness." The joint control of the canal would scarcely come within the specific utterance of Monroe but its intimate relations "to our power and prosperity as a nation, to our means of defense, our unity, peace, and safety" would justify an exclusive canal policy as a reasonable measure of self-defense.

The most startling application of the Monroe Doctrine was made by President Cleveland against England for refusing to arbitrate a boundary dispute between British Guiana and Venezuela. The British extended their boundary lines westward in I 840 and continued to do so from time to time afterward. The Venezuelan Government began asking for arbitration in $188 \mathrm{I}$, appealed to the United States for aid, and severed diplomatic relations with England in 1887. The United States requested England to arbitrate its differences; alluding indirectly to the Monroe Doctrine, but expressing the belief that no thought of political or territorial expansion was controlling the British policy. The suggestion of arbitration was repeated by Secretary Gresham in 1894 but to no avail.

On July 20, 1895, Secretary of State Olney sent to Great Britain one of the most astounding mes- 
sages in the history of American diplomacy demanding a definite decision in the question of arbitration. He relied implicitly upon the Monroe Doctrine which he reviewed at length. He declared that, "Today the United States is practically sovereign on this continent, and its fiat is law upon the subjects to which it confines its interposition." This is so because "in addition to all other grounds, its infinite resources combined with its isolated position render it master of the situation and practically invulnerable as against any or all other powers." $\mathrm{He}$ concluded with the declaration that the English position "will be regarded as injurious to the interests of the people of the United States."

Olney's dispatch was made public with President Cleveland's equally remarkable message of December 17, I895. Placing implicit reliance upon the "Monroe Doctrine which is strong and sound "because its enforcement is important to our peace and safety as a nation" and which was "intended to apply to every stage of our national life and cannot become obsolete while our republic endures" he declared that by extending her boundaries to cover the territory of a neighboring republic, England was attempting "to extend its system of government" to this continent, which Monroe had declared was "dangerous to our peace and safety." The Monroe Doctrine was declared to be international law because "based upon the theory that every 
Evolution of the Doctrine: I869-19I8 7I

nation shall have its rights protected and its just claims enforced." The time had come for the United States to determine the true boundary and to "resist by every means in its power," the appropriation of any land by Great Britain which belonged to Venezuela. The message closed with these portentous words: "In making these recommendations I am fully alive to the responsibility incurred and keenly realize all the consequences that may follow."

While the message startled the American people and astonished England, the former rallied to the support of the President. Lord Salisbury's able reply afforded a complete refutation of the futile effort to give to the Monroe Doctrine the binding character of law. He argued that the present case did not come within any of the principles laid down by President Monroe, that England itself had interests in America which were natural and legitimate and that he was not prepared to "admit that the interests of the United States are necessarily concerned in every frontier dispute which may arise between any two of the states that possess dominion in the Western Hemisphere." He did not make any headway, however, against America's conviction that her fundamental interests were at stake and eventually England agreed to arbitration which was decided in her favor. England thus acquiesced in our policy of paramount interest in the Americas. 
Just why the Venezuela incident should have evoked such a vehement assertion of American policy it is indeed difficult to determine. The doctrine here announced was the Doctrine of Paramount Interest and about the only thing in common with the Monroe Doctrine was the idea of selfdefense through the political peace and stability of the Western Hemisphere. There can be no doubt, however, that the President's outburst received much popular support by virtue of its appeal to the hallowed doctrine of Monroe. Happily Lord Salisbury did not permit the incident to estrange the British public as might reasonably have been expected. He was greatly aided in this respect by the publication of the German Emperor's telegram of congratulations to the president of the Boer republic on the occasion of Jameson's Raid which proved to be very effective as a counter-irritant. The subsequent conduct of Great Britain in the Spanish American War and the consummation of the Hay-Pauncefote Treaty afforded ample evidence of the growth of British friendship and understanding.

It was only a short time before Venezuela afforded another opportunity for the application of our traditional foreign policy by its failure to make reparation to England for injuries to the persons and property of its citizens and to pay similar and other claims to Germany and Italy. Our general 
policy on the subject was enunciated in President Roosevelt's annual message of December 3, 1901, when he observed that,

The Monroe Doctrine is a declaration that there must be no territorial aggrandizement by any nonAmerican power at the expense of any American power on American soil. It is in no wise intended as hostile to any nation in the Old World. . . . This doctrine has nothing to do with the commercial relations of any American power, save that it in truth allows each of them to form such as it desires. . . . We do not guarantee any state against punishment if it misconducts itself provided that punishment does not take the form of the acquisition of territory by any non-American power.

On December II of the same year the German ambassador at Washington stated that if Venezuela should persist in its refusal to consider Germany's claim that his government would have to resort to a blockade of the Venezuelan ports and perhaps to "temporary occupation" and the "levying of duties" but "that under no circumstances do we consider in our proceedings the acquisition or the permanent occupation of Venezuelan territory." Great Britain gave a like assurance to the United States in November, 1902. Secretary Hay replied that his government, although it " regretted that European powers should use force against Central and South American governments, could not object 
to their taking steps to obtain redress for injuries suffered by their subjects, provided that no acquisition of territory was contemplated." Under the pressure of the blockade Venezuela consented to submit her claims to arbitration.

In a public address in Chicago in 1903, President Roosevelt restated the American policy as applied on that occasion.

The concern of our government was of course not to interfere needlessly in ary guarre! 50 far $z$ it did

- not touch our interests of cur honor, and not to take the attitude of protecting from coercion any power unless we were willing to esponse the quarte! of that power, but to keep an atticude of watchful vigilance and see that there was no infririgement of the Monroe Doctrine, no acquirement of territorial rights by a European power at the expense of a weak sister republic - whether this acquisition might take the shape of an outright and avowed seizure of territory or of the exercise of control which would in effect be equivalent to such seizure. . . Both powers assured us in explicit terms that there was not the slightest intention on their part to violate the principles of the Monroe Doctrine, and this assurance was kept with an honorable good faith which merits full acknowledgment on our part. At the same time the existence of hostilities in a region so near our own borders was fraught with such possibilities of danger in the future that it was obviously no less our duty to ourselves than our duty to humanity to endeavor to put an end to that. Accordingly, by an offer of our good services in a spirit of frank friendliness to all 
the parties concerned, a spirit in which they quickly and cordially responded, we secured a resumption of peace - the contending parties agreeing that the matters which they could not settle ameng themselves should be referred to The Hague Tribunal for settlement.

The incident foreshadowed the development of American responsibility under the Monroe Doctrine which was to force us, "however reluctantly; in. flagrant cases of such wrongdoing or impotence, to the exercise of an international police power," particularly in the Caribbean countries. This is considered in another chapter.

During this period, Cuba continued to play a part in American diplomacy. In 1866 the first spontaneous movement for independence broke out. There followed a period of lawlessness and filibustering, with the usual claims for damages to the lives and property of foreigners, including citizens of the United States. There seemed no chance to appeal to the Monroe Doctrine. Secretary Fish, turning his back to it, summoned the leading European nations to a joint intervention. Spain sensed the danger and promised reforms in Cuba, which were put into effect in 1878 , and the question was solved for the moment.

The war broke out again in 1895 with the establishment of the Cuban Republic. There was never any responsible or effective government and all the 
fighting done was in guerilla warfare. Plantations were devastated, crops and property were destroyed, and commerce was impaired. This was a case of a European power fighting to reduce its colony and did not in any way involve an infraction of the specific principles laid down by President Monroe. Nevertheless there were American interests at stake, and in 1896 Secretary Olney wrote the Spanish Government that the American people were

. . . interested in any struggle anywhere for freer political institutions, but necessarily and in special measure in a struggle that is raging almost in sight of our shores. . . . The interest of the United States in the existing situation in Cuba yields in extent only to that of Spain herself, and has led many good and honest persons to insist that intervention to terminate the conflict is the immediate and imperative duty. of the United States . . . . the United States cannot contemplate with complacency another ten years of Cuban insurrection, with all its injurious and distressing incidents.

In spite of a growing demand in the United States for annexation or recognition President Cleveland maintained a policy of neutrality.

Under President McKinley the pressure for intervention continued and was greatly accelerated by the destruction of the United States battleship Maine in the harbor of Havana. Finally on April I I, 1898, the President sent a message to Congress 
to the effect that armed intervention would be necessary to end the war. He justified his action on the ground of American interests.

The present condition of affairs in Cuba is a constant menace to our peace and entails upon this government an enormous expense. With such a conflict waged for years in an island so near us and with which our people have such trade and business relations; when the lives and liberty of our citizens are in constant danger and their property destroyed and themselves ruined; where our trading vessels are liable to seizure and are seized at our very door by ships of a foreign nation; the expeditions of filibustering that we are powerless to prevent altogether, and the irritating questions and entanglements thus arising all these and others that I need not mention, with the resulting strained relations, are a constant menace to our peace and compel us to keep on a semi-war footing with a nation with which we are at peace.

The war led to unexpected results in the acquisition of Porto Rico, Guam, and the Philippine Islands. America became a world power; the "Two Spheres" doctrine became correspondingly weaker. and our foreign policy more aggressively one of American interest.

At the time of the declaration of war, Congress passed the Teller Resolution which disclaimed for the United States any intention of annexing Cuba and promised to leave "the government and control of the island to its people." Realizing that this fre- 
quently is more easily said than done, particularly among Latin American republics, Congress adopted what is known as the Platt Amendment. It provided that Cuba should adopt a constitution which would bind that nation to conclude a treaty with the United States to the effect that Cuba should make no treaty that would impair her independence, nor allow any portion of the island to pass under the control of a foreign power. No debt should be con$*$ tracted or assumed beyond the country's ability to pay, and the United States should have the right to intervene to insure Cuban independence and to afford protection for life, liberty, and property. The protection of American interests in Cuba and the enforcement of our traditional foreign policy were thus facilitated by an express agreement, the wisdom of which has been amply justified by subsequent experience. It was a definite step towards the assumption of that international guardianship which was destined to become an established method of protecting American interests in the Caribbean. At The Hague Conference in 1899 occasion was offered for the United States to substitute arbitration for the policy of dominant interest in her dealings with American nations and problems. During the discussion of the convention for international peace it was suggested that,

The signatory Powers consider it their duty, if a serious dispute threatens to break out between two 
or more of them, to remind these latter that the Permanent Court is open to them.

The American delegates feared that the proposal might place their country in an embarrassing position if a case arose involving American interests on this hemisphere and the powers should "remind" the United States of the possibility of arbitration. To meet the contingency a reservation was presented by the American delegates and accepted by The Hague Conference which provided that,

Nothing contained in this convention shall be so construed as to require the United States of America to depart from its traditional policy of not entering upon, interfering with, or entangling itself in the political questions or internal administration of any foreign state; nor shall anything contained in the said convention be so construed as to require the relinquishment, by the United States of America, of its traditional attitude toward purely American questions.

This was included in the ratification by the Senate, and a similar reservation was made and accepted in The Hague Convention of 1907.

Every member of the Conference understood the term "traditional attitude toward purely American questions" to mean the Monroe Doctrine. That the United States has such a traditional policy is thus universally and officially admitted. How much 
agreement there will be as to its definition and application to concrete questions as they arise will continue to be a matter of doubt and speculation.

Other interests and events affecting the Monroe Doctrine during this period, such as the protectorates in the Caribbean and American interests in the Pacific will be considered in later chapters. The general trend in the evolution of the Monroe Doctrine, however, is well evidenced by the instances already cited.

The long controversy with England to get her to relinquish lawfully acquired treaty rights in the canal could not possibly be brought under any of the specific phases proclaimed by President Monroe. America's paramount interest was the one argument that England could not answer. The canal's obvious relation to our peace, prosperity, and defense was the logic against which a friendly Fngland could not successfully contend. The first Venezuelan controversy might possibly be brought within the specific principles of Monroe as a scheme of camouflaged colonization, but in reality our position was that our peace and safety demanded that England's conduct in Latin American affairs must conform to certain standards that we declare. The second Venezuelan incident did not involve the colonization principle enunciated by Monroe, for we went much further and declared. that American territory could not be acquired in 


\section{Evolution of the Doctrine: 1869-1918 81}

good faith and for legal cause, because inimical to American interests. The war with. Spain was obviously a case of defending our dominant interest in the Caribbean.

As the years pass the occasions for the assertion of the specific principles of Monroe will less frequently arise. But the time will never come when the underlying principle - the principle of self-defense - will not require a policy of statesmanship and foresight to avoid the perils that will beset our national progress. We may call this evolving policy the Monroe Doctrine, the Doctrine of Paramount Interest, or as suggested by Professor Hart, the American Doctrine. Designated as the Monroe Doctrine our foreign policy will doubtless secure a popular response because of its historic glamour and its appeal to American idealism and pride of achievement which perhaps another name, or the bald statement of specific interests, would not arouse. Whatever its name, its vitality and force will depend upon its capacity to serve the national needs. Attempts at restrictive definition must be abortive. The policy that endures must be evolved from the wisdom, conscience, and imagination of the American people as from decade to decade they grapple, with the problems that bar the pathway of national destiny. 


\section{CHAPTER V}

THE PACIFIC AND THE FAR EAST

A MERICAN interests in the Far Pacific in 1823 A were of so little importance that it has never been supposed that the Monroe Doctrine was intended to apply there. It is true that the colonization clause had specific reference to the Oregon controversy on the Northwest Coast and the Bering Sea, but it was obviously not expected to operate beyond the neighboring waters that washed our western shores.

In 1784 the first American vessel reached China and in 1786 an American commercial agent was in residence there. Nevertheless our trade was very meager until the treaty of 1844 , which opened up five Chinese ports to American commerce. These privileges were amplified by the treaty of 1858 , which also granted religious liberty and paved the way for missionary enterprise.

In I854 Commodore Perry succeeded in opening up the empire of Japan that had been closed to the nations of the world for generations. Japan dates its new life from that event. Other treaties followed in 1857 and 1858 . In the meanwhile commer- 
cial treaties were concluded with Hawaii in 1849 , with the Sultan of Brunei in Borneo in 1850, and with Siam in 1856.

With this increase of American interests in the Pacific, the attention of the United States began to be attracted to Hawaii. In 1842, commissioners appeared in Washington asking for the recognition of the Hawaiian Kingdom. Secretary of State Webster declared that the United States was more interested in the fate of the islands than any other nation could be. It was the feeling of his government that the

Sandwich Islands ought to be respected; that no power ought either to take possession of the islands as a conquest, or for the purpose of colonization; and that no power ought to seek for any undue control over the existing government, or any exclusive privileges or preferences with it in matters of commerce.

This indicated very clearly the feeling that America's interest in Hawaii was paramount. This same idea was expressed by President Tyler in a special message. He stated that while the United States sought no peculiar advantage or exclusive control in Hawaii, yet the large intercourse between America and the island would justify his government, "should events arise to require it, in making a decided remonstrance against the adoption of an opposite policy by any other power." 
The following year a British ship of war, becoming engaged in a controversy with the little monarchy, ran up a British flag. The King complained to the United States and asked them to intervene. An American warship was sent to the islands to remonstrate and our minister to London protested. That same year Great Britain and France, both of whom had designs on the islands, agreed to consider them "as an independent state and never to take possession, either directly or under the title of protectorate, or under any other form, of any part of the territory of which they are composed."

In 1849 a French naval officer sought to secure some special privileges in the islands but the United States objected. Secretary of State Clayton explained that,

The situation of the Sandwich Islands, in respect to our possessions on the Pacific and the bonds commercial and of other descriptions between them and the United States, are such that we could never with indifference allow them to pass under the dominion or exclusive control of any other power. We do not ourselves covet sovereignty over them. We would be content that they should remain under their present rulers.

This led to the proposal for the annexation of the islands to the United States in $185 \mathrm{I}$. It met with little favor from Secretary Webster, but re- 
ceived encouragement from Secretary Marcy two years later. He did not think the Hawaiian Government could long remain in the hands of its present rulers. Both England and France had been apprised of the intention of the United States not to allow them to fall into the hands of European nations. He argued:

It seems to me inevitable that they must come under the control of this government, and it would be but reasonable and fair that these powers should acquiesce in such a disposition of them, provided the transference was effected by fair means. . . . This government will receive the transfer of the sovereignty of the Sandwich Islands with all proper provisions relative to the existing rights and interests of the people thereof, such as are usual and appropriate to territorial sovereignty. The United States would not regard with unconcern an attempt on the part of any foreign power, and especially any European maritime, power, to disturb the repose or interfere with the security of the Hawaiian Islands.

A treaty was drafted by which Hawaii was to become a state of the Union, but it never came before the Senate and was finally dropped. Friendly relations were continued with the islands until their final annexation to the United States by joint resolution in 1898 .

While the authority of Monroe was not invoked in the case of Hawaii, the argument and phraseology are familiar to the student of the Monroe 
Doctrine in its later development. The words of Secretary Clayton that "we could never with indifference allow them to pass under the dominion . . . . of any other power" have a familiar ring. It is the old doctrine of dominant or permanent interest, an interest that we could reasonably expect friendly nations to recognize. Therefore any nation that would dispute it would be guilty of an unfriendly act which "would justify this government . . . . in making a decided remonstrance" against it. Like all successful foreign policies it rested upon the principle of self-interest. The distinction between the American policy as applied to Hawaii and as applied to Latin America is not one of kind, but of degree. In the former case foreign control would not clearly jeopardize the fundamental conditions essential to American peace and safety while in the latter case they would. In both cases it was a policy in defense of American interests, but interests which differed vastly in their importance to the national well-being.

From time to time the United States has been interested in other islands in the Pacific, but none of them, with the exception of the Philippines, has been of sufficient importance to call for a formal enunciation of important policies. It is obvious, however, that if the policy of giving the Philippines their independence, ultimately prevails, we will be confronted with a portentous problem. It is scarcely 
conceivable that we could give them their independence without retaining some responsibility for their protection, such as was involved in the Platt Amendment in regard to Cuba. The statesman of that day will doubtless find some phase of traditional policy that may prove available. Article $\mathrm{x}$ of the proposed League of Nations would, perhaps, suffice. However, that case would be more a matter of altruistic concern than of national interest.

In 1912 there occurred the Magdalena Bay episode which aroused much discussion, resulting in a significant resolution by the United States Senate. In the southern part of Lower California is a large bay. The surrounding country is barren. Moss containing dye and fish are about the only commercial interests, though there are possibilities of lumber and cattle. An American company secured here from Mexico a tract of several million acres. It turned out unprofitable and an effort was made to sell it to certain Japanese subjects. The matter was submitted to Secretary of State Knox, who opposed the sale on the ground that "such a transfer would be quite certain to be interpreted in a manner to cause a great outcry." The Japanese Government had nothing to do with the scheme and subsequently assurance to that effect was officially given. The position of the secretary was supported by the Senate in passing the Lodge Resolution, which read: 
Resolved, That when any harbor or other place in the American continents is so situated that the occupation thereof for naval or military purposes might threaten the communications or the safety of the United States, the government of the United States could not see without grave concern the possession of such harbor or other place by any corporation or association which has such a relation to another government, not American, as to give that government practical power of control for naval or military purposes.

The discussion leading up to the resolution shows that its author did not regard it as an extension of the Monroe Doctrine but as based upon the fundamental principle of self-defense.

It has been suggested that since the purchase was for private commercial use only, the Lodge Resolution was both inapplicable and too strong. A frank, dignified statement of such an American policy on

- the proper occasion would seem sound and reasonable, but when issued under such circumstances its - needlessly suspicious attitude does not breed inter-national good will. As observed by Professor Hart, the American attitude towards Japan's acquiring interests on this side of the Pacific may not be logically consistent with our retention of the Philippines off the coast of Japan, but it is firm and has its basis, in American interests.

The military and naval power of Japan make it necessary for the United States to apply to Asiatic 
influence in America the same principle that she maintains with regard to European interests. So far as the Monroe Doctrine has force and meaning and reason, it is as good against Asia as against Europe. The time may come when it will be asserted against Australia. The true American doctrine is directed, not against this or that power, but against a state of foreign mind, unfavorable to the interests of the United States in America.

The two great principles of American foreign policy are the Monroe Doctrine and the "OpenDoor" in China. In 1898 England, Germany, France, and Russia secured by lease from Čhina different sections of Chinese territory. Italy sought certain concessions at the same time and Japan, as a result of her previous war with China, had obtained Corea. There seemed to be a tacit understanding among these powers that China might be divided between them into "spheres of influence" which very conceivably might develop into European colonies. In any event it was to be feared that the great powers would seek to monopolize the commercial opportunities of China. America with her growing interest in the Pacific, could not view these circumstances with equanimity. Secretary of State Hay in September, I899, sent to the powers concerned a circular note asking for declarations in favor of open trade which has since become known as the "Open-Door" policy. This was formally acceptod by England only, although 
the other powers expressed agreement with the principles enumerated in the note.

In the meantime a popular movement against the "foreign devils" and especially the missionaries broke out in China. Popular indignation was vented in the destruction of lives and property and the foreign legations in Peking were besieged. This meant immediate intervention for the protection of foreign interests which might very easily lead to great inroads into the territorial and administrative entity of China under the guise of exacting full indemnities for injuries done and adequate security for the future. With masterful statesmanship, Secretary Hay seized the leadership in this grave international crisis. In July, I900, he announced the policy of the United States, which was to hold the responsible authors of injury to American citizens "to the uttermost accountability." Where the Chinese officials sought to protect foreign life and property they would be regarded "as representing the Chinese people, with whom we seek to remain in peace and friendship." The President will cooperate, he declared, with the great powers in protecting American property and

. . . . in aiding to prevent a spread of the disorders to the other provinces of the empire and a recurrence of such disasters. It is of course too early to forecast the means of attaining this last result; but the policy of the government of the United States is to seek 
a solution which may bring about permanent safety and peace to China, preserve Chinese territorial and administrative entity, protect all rights guaranteed to friendly powers by treaty and international law, and safeguard for the world the principle of equal and impartial trade with all parts of the Chinese Empire.

For the time being the principles of the American policy seemed to prevail, but without an alliance with England and Japan, America has been unable permanently to resist the forces that opposed.

Like the Monroe Doctrine, our Far Eastern policy had its altruistic aspects. While primarily concerned with the protection of commercial interests in the Orient, Hay accomplished it temporarily by protecting the administrative and territorial entity of China against possible invasion by European powers. He protected American commerce, not by seeking special concessions or exclusive spheres, but by establishing the principle of "equal and impartial trade" for all.

America sought to secure her peace and safety in the New World by safeguarding Latin American republics from foreign aggression and in later years by preventing the acquisition of economic claims that might develop into political power. So in Asia she has sought the protection of her interests in preserving the integrity of China, and opposed the imposition of commercial schemes that might ripen into political aggrandizement. 
One incident in the Far East remains to be briefly noticed and that is Japan's Monroe Doctrine for Asia. With the outbreak of the European war in I9I4, Japan, as one of the allies, prepared to besiege Tsing-tao, capital of Kiao-Chau, a province leased by Germany, official notice being given to the United States that the province would be returned to China. This was not done and it was soon learned that Japan was pushing an unfavorable treaty upon the Chinese. The proposed treaty included twenty-one demands, so sweeping in extent, that, if granted, it meant vassalage for China. They provided for a thorough domination of China's economic and political affairs. The proposal, finally backed up by an ultimatum, aroused the indignation of China and caused grave concern to the United States as well as to Japan's allies. China was forced to accept the treaty, being powerless to resist.

Defenders of Japan's policy relied much upon Japan's Monroe Doctrine for Asia, which it was asserted, was the mere application of the same principles to Asia that the United States had applied to the Americas. Japan did not cease all of this time to insist that she did not propose to interfere with Chinese integrity, the "Open-Door" or the treaty rights of any other power. It was argued that since Japan respected the Monroe Doctrine of America, that we should respect the Monroe Doctrine of Japan. The argument did not find popular 
response in America, where Japan's attitude created undisguised suspicion and hostility.

It has been argued that it is to American advantage to support the policy of Japan and thus drive from. China the competition of Europe, for it is with the latter that we have the strongest contest for Oriental trade. Furthermore, such an attitude would make for harmony and understanding between the two peoples. To this it is answered that if we drive European powers from China and gain the friendship of Japan, we force these powers to seek their markets in Latin America, thus increasing the strain upon the Monroe Doctrine and gaining the ill-will of European friends. Moreover, it is argued that Japan's attempt to defend her policy by the analogy to the Monroe Doctrine is not accurate or fair. It is a policy of aggression and not defense; it tends to destroy the integrity of China rather than to preserve it; and finally, despite assertions to the contrary, it seeks exclusive rights for Japan rather than equal opportunities for all. When these, things are considered together with the relative size and population of Japan and China, it is not surprising that the new Monroe Doctrine for Asia has aroused suspicion and resentment in America and in the world.

Late in 1917 there was an exchange of identical notes between the representative of Japan and the United States, commonly referred to as the Ishii- 
Lansing agreement, by which the spirit of suspicion and hostility between the two countries was sought to be removed and a basis of mutual sympathy and understanding achieved. The notes recognized the special interest of Japan in China, "particularly in the part to which her possessions are contiguous," but also declared for the preservation of Chinese integrity and independence, and stated their adherence "to the principle of the so-called 'OpenDoor' or equal opportunity for commerce and industry in China." This agreement, on its face, seems to accord with the traditional ideals and principles of American policy, and if carried out in that spirit will be a source of helpfulness for China and afford a sound basis for mutual understanding between America and Japan. 


\section{CHAPTER VI}

DOLLAR DIPLOMACY AND THE CARIBBEAN

WRITING in 19I4, ex-President Taft observed that the Monroe Doctrine

. . . is based on a wise policy in our own interest to exclude from this hemisphere the selfish political interference of European governments and their appropriation of territory, not for the purpose of increasing our power or territory, but for the purpose of promoting the prosperity, independence, and happiness of the peoples of these two continents and so of insuring our own peace and safety.

While no clean-cut cases of "selfish political interference " or of " appropriation of territory" have arisen in recent years, certain conditions in the Caribbean countries have called for the utmost vigilance to prevent European powers, who have acquired commercial holdings in the Caribbean, from merging these interests into political dominion.

In this group of Latin American powers, the governments generally are not strong, life and property are insecure, revolutions are frequent, and the collection of both public and private debts is extremely uncertain. As a result European countries 
are frequently called upon by citizens to enforce their claims. The nation may be bankrupt or may refuse a settlement. The European countries may then seek to take over temporarily the fiscal administration of the country to secure the payment of their claim, they may take a portion or all of the territory in satisfaction of their demands, or they may by a show of force compel their immediate payment if the funds are actually available. It is obvious that the first two alternatives would constitute that "political interference" or "appropriation of territory" that would violate our established policy, and it is equally clear that the last alternative is not only dangerous to American interests but in many cases would be abortive.

We cannot safely permit European nations to occupy American territory, and yet to deny them what may be the only effective means of redress, is indefensible. This situation has forced the United States to a third alternative-interference in the affairs of these weak republics so far as it is necessary to settle the just claims of foreign powers. President Roosevelt in expressing this new phase of our policy has said:

If a nation shows that it knows how to act with reasonable efficiency and decency in social and political matters, if it keeps order and pays its obligations, it need fear no interference from the United States. Chronic wrongdoing, or an impotence which results 
in a general loosening of the ties of civilized society, may in America, as elsewhere, ultimately require in. tervention by some civilized nation, and in the Western Hemisphere the adherence of the United States to the Monroe Doctrine may force the United States, however reluctantly, in flagrant cases of such wrongdoing or impotence, to the exercise of an international police power.

In fact this policy was anticipated in the statesmanlike utterance of President Hayes against a joint Isthmian Canal when he declared that the capital invested

degree, look for protection to one or more of the great powers of the world. No European power can intervene for such protection without adopting measures on this continent which the United States would deem wholly inadmissible.

Therefore, to avoid such intervention, the United States should have supreme control. The provisions of the Platt Amendment that gave to the United States the right to intervene in Cuba to protect life, liberty, and property, and that bound that island not to contract any debt beyond its abilitic:s to pay, were in furtherance of the same principle. This gave the United States the means by which foreign aggression under the guise of collectin? claims, could be effectively prevented. The active part played by the United States in persuading 
Venezuela to submit the claims of England, Germany, and Italy to arbitration indicated our keen sense of responsibility for ,Latin American behavior. President Roosevelt was merely developing and applying these same principles to the specific case before him.

The case of Santo Domingo afforded the first clear example of the application of this new aspect of our foreign policy. Santo Domingo had been the scene of countless revolutions. For seventeen years Ulysses Heureaux ruled by a policy of terrorism. A semblance of law and order was secured, but with his assassination in 1899 , the little republic lapsed into its original state of chronic lawlessness. By 1904 the national debt was thirty-two million dollars, and not even the interest could be paid. European intervention was threatened and it was rumored that French and Italian vessels were on the way. An appeal was made to the United States. President Roosevelt was confronted squarely with the problem of assuming responsibility for the finances of the bankrupt government or seeing European countries seek relief by methods that might be inimical to the interests of his government.

President Roosevelt drew up a protocal which virtually made this government a receiver for the bankrupt country. The United States was to adjust all claims of foreign creditors and assume control of the customhouses. Fifty-five per cent of the 
receipts were to be applied to the cost of collecting the customs and the reduction of the debt and interest, the other forty-five per cent to be applied to domestic expenses. The Senate refused to ratify the treaty, and President Roosevelt entered into an executive agreement with the republic embodying practically the same terms. The President justified his general policy because,

There was imminent danger of foreign intervention. The previous rulers of Santo Domingo had recklessly incurred debts, and owing to her internal disorders she had ceased to be able to provide means of paying the debts. The patience of her foreign creditors had become exhausted, and at least two foreign nations were on the point of intervention, and were only prevented from intervening by the unofficial assurance of this government that it would itseif strive to help Santo Domingo in her hour of need. In the case of one of these nations, only the actual opening of negotiations to this end by our government prevented the seizure of territory in Santo Domingo by a European power.

The agreement was so successful that, two years later, a new treaty, embodying the same general policy, was negotiated and ratified. The public debt, which was scaled down to twenty million dollars by discarding fraudulent claims, was refunded by New York bankers. Since then the island has been more tranquil and the fear of European interference has passed. There have been a few revolu- 
tions and we have had to land marines at election times, but the possibility of genuine prosperity when life and property are reasonably secure seems amply assured. On this occasion President Roosevelt observed that,

We-do not intend to permit the Monroe Doctrine to be used by any nation on this continent as a shield to protect it from the consequences of its own misdeeds against foreign nations. If a republic to the south of us commits a tort against a foreign nation, such as an outrage against a citizen of that nation, then the Monroe Doctrine does not force us to interfere to prevent punishment of the tort, save to see that the punishment does not assume the form of territorial occupation in any shape. The case is more difficult when it refers to a contractual obligation. . . . On the one hand, this country would certainly decline to go to war to prevent a foreign government from collecting a just debt; on the other hand, it is very inadvisable to permit any foreign power to take possession, even temporarily, of the customhouses of an American republic in order to enforce the payment of its obligations; for such temporary occupation might turn into a permanent occupation. The only escape from these alternatives may at any time be that we must ourselves undertake to bring about some arrangement by which so much as possible of a just obligation shall be paid.

In December, I909, President Zelaya, of Nicaragua, was swept from office by a revolution. The finances were hopelessly involved, and the new gov- 


\section{Dollar Diplomacy and the Caribbean Ior}

ernment looked to the United States for help. A convention was drawn providing that loans advanced to Nicaragua by American bankers should be secured by placing American officials in charge of customs. The Senate failing to ratify the treaty, President Taft carried out its policy by an executive agreement. The proceeds were to be employed in the common interest of Nicaragua, the American bankers, and British creditors. Later another treaty was signed in which the United States agreed to pay three million dollars to Nicaragua, to be expended on public works and education, in return for which the latter country was to grant to the United States exclusive and perpetual canal rights across its territory, a naval base on the Gulf of Fonseca, and substantial control of finances and foreign relations. America would thus obtain a protectorate. The treaty was not then accepted by the United States Senate but was later ratified in 1916, some minor changes having been made in the meantime. The political relations were similar to those established with Cuba by the Platt Amendment.

In Nicaragua the United States followed its policy of interfering with the consent of the country, and assuming responsibility for its financial integrity as well as for its national independence. To do otherwise would be to leave them to the mercy of unscrupulous dictators and ultimately to 
invite intervention by foreign powers. When public funds are secure in American hands against the attacks of revolutionary mobs, foreign creditors are paid and revolution loses its peculiar charm.

In the meanwhile conditions in Haiti were rapidly coming to a climax. For the last decade conditions had been growing steadily worse. The people were hopelessly incompetent for self-government. The climax came in I9I4 when Germany and France made formal demand for the control of the customs. The outbreak of the European war prevented this, and subsequently Haiti suspended payments on all its obligations. Revolution again broke out; the Dominican and French legations were outraged, the United States was compelled to land marines to establish order, and finally, in the summer of 1915, to take over the administration of the customs. In September a treaty was negotiated which later was ratified by both governments. Its chief provisions were:

(I) A Haitian receivership of custom under American control ;

(2) American supervision of all expenditures of public money;

(3) American control of the native constabulary;

(4) A pledge by Haiti not to cede or lease territory to a foreign power;

(5) All revolutionary forces were to be disarmed, q 
Dollar Diplomacy and the Caribbean 103

(6) The United States was to "lend an efficient aid for the preservation of Haitian independence and the maintenance of a government adequate for the protection of life, property, and individual liberty."

The responsibility here assumed by the United States. was especially great because of the unusual, amount of internal supervision involved, the turbulent character of the population, and the great economic resources of the country. Nevertheless, the administration at Washington did not hesitate to assume the burden. The peace and security of the Caribbean was at stake. This meant that American interests were endangered.

It was the same sense of American interest and responsibility that led the United States in 1907 to encourage the Central American states to establish and maintain peaceful and orderly relations between themselves resulting in several treaties and the creation of the Central American Court of Justice. Likewise, we have not been unmindful of our responsibility for Cuba. Twice, in 1906 and in I9I6, we have intervened there to insure orderly elections and to protect the machinery of government from disorderly hands. Intervention was imminent again in I9I I and I9I2.

The premature recognition in 1903 of the independence of Panama, two days after its nominal revolt from the United States of Colombia, does 
not fit into the spirit or theory of American foreign policy and forms an anomalous exception. While done under mitigating circumstances it was an improper disregard of established rights which has caused much enmity and distrust among our Latin American neighbors.

The American policy in the Caribbean is but the development of the specific principles necessary to protect our paramount interest. The military importance of preventing European nations from acquiring territory in the Caribbean can be easily conceived when we imagine Haiti in the possession of Germany and a base of operations in the present war. The commercial significance of our policy is apparent when we consider the effect upon our foreign trade if the Caribbean countries were controlled by European powers and our Caribbean trade subjected to discriminating tariffs.

Our total exports to Latin America have almost quadrupled from 1890 to 1912 , while our imports from the Caribbean regions have increased from $\$ 88,000,000$ in 1902 to $\$ 242,000,000$ in 1914 and our exports have shown an increase from $\$ 73,000$,$\infty 00$ to $\$ 190,000,000$ during the same period. The United States is rapidly becoming a manufacturing nation. For years the balance of trade has been in our favor. That means that the continuance of our national prosperity will ultimately require new opportunities for the investment of our surplus 
capital, expanding markets for our goods and larger sources of raw material. The Caribbean countries by reason of their proximity to us and of the character of their exports, being almost exclusively raw material, affords America a splendid opportunity.

For these same reasons European countries are attracted to the Caribbean. The protection of American interests as well as the welfare of the Caribbean require that no European power exercise political dominion over them, but that their trade shall be open on equal terms to the nations of the world. These same interests also require security for life and property as the requisites for their economic and political development. To secure these interests has been the immediate object of American policy. In most of the Caribbean countries life and property were insecure, the nations were frequently involved in debts they were unable to pay, while revolutions for the control of the customs kept the lands in continual turmoil. Either the United States had to step in and assume responsibility for their financial and international obligations or European nations would. The United States wisely chose the former course.

This policy has been condemned as Dollar Diplomacy, as dictated by our commercial interests, as prostituting the political doctrines of Monroe to the service of commercial aims. The phrase "Dollar Diplomacy" had certain sinister connotations which 
the demagogue and politician were quick to see and capitalize. It is significant, however, that when confronted with the actual problem rather than with the exigencies of political abuse, the administrations of Roosevelt, Taft, and Wilson have agreed on fundamental policy. This policy does not stand for economic exploitation or for territorial aggrandizement for commercial ends. It does seek to meet the conditions as they exist and to oppose territorial aggrandizement of others. Economic interest in backward countries, unable to protect life and property, tend to ripen into political authority, under the guise of protecting the rights of nationals. Against this evil our foreign policy has been successfully invoked. If it has protected the interest of American bankers and American commerce, it has protected alike the interest of creditors and commerce everywhere. If the American policy as developed in the Caribbean is an economic doctrine it is so because the problems are economic but with a deep political significance that we dare not ignore. As observed by Professor Chester Lloyd Jones, a careful student of Caribbean problems,

This will be for the benefit of the foreign bondholders in that they will know that they are not running risks of such speculative nature as has formerly been the case. It will be to the benefit of the smaller states in that they will be protected against their own improvidence. It will be to the benefit of the United 
States in that, the political character of the investments being removed, the temptation of the European powers to call into question the Monroe Doctrine will be lessened.

The inherent relation between political and economic interests in Latin America is convincingly set forth in President Wilson's Mobile address.

You hear of "concessions" to foreign capitalists in Latin America. You do not hear of concessions to foreign capitalists in the United States. . . They are invited to make investments. . . . It is an invitation, not a privilege; and states that are obliged, because their territory does not lie within the main field of modern enterprise and action, to grant concessions are in this condition, that foreign interests are apt to dominate their domestic affairs: a condition of affairs always dangerous and apt to become intolerable. What these states are going to see, therefore, is an emancipation from the subordination, which has been inevitable, to foreign enterprise. They have had harder bargains driven with them in the matter of loans than any other peoples in the world. . . . I rejoice in nothing so much as in the prospect that they will now be emancipated from these conditions, and we ought to be the first to take part in assisting in that emancipation. . . .

Again the United States has sought in other means the protection of weak states against the forces of powerful creditors. At The Hague Conference in 1907 the American representatives were instructed to support the Drago Doctrine to limit 
the freedom of action in the collection of public debts. A resolution was passed stipulating that there shall be no collection of public debts by force except where the debtor refuses arbitration, makes it impossible, or declines to abide by the award.

The American policy in the Caribbean has not always met with the approval of our southern neighbors. It has been urged that it violates a fundamental concept of international law - the equality of nations. And in a sense this is true. International law makes no distinction between independent nations. In strict legal theory they are all equal. In fact, however, there are infants among nations as there are among human beings. The United States has recognized that fact and assumed the guardianship of those nations incapable of protecting their independent existence. But it must be remembered that where intervention in the affairs of independent nations has taken place, it has generally been with governmental consent, and that the United States has not attempted to apply this doctrine to the stronger South American powers whose ability to maintain their own independence is no longer doubted.

Other criticisms of our policy have emanated from Latin America from time to time that need not be considered here. Suffice it to say that too frequently our neighbors forget that this is the policy of the United States, enunciated, supported, and 
enforced by them and for the protection of their interests. True it is that it has its altruistic side from which it derives much of its popular support. As an American policy it has been successful. By providing for the stability and independence of American republics it has secured our peace and safety. By safeguarding the weaker nations against the economic and political exploitation of European powers it has secured to us equal commercial opportunities in the American tropics. By preventing the annexation of territory by foreign nations it has safeguarded our material interests and given added security to the Panama Canal.

But with these purely nationalistic gains have gone those altruistic by-products that are the pride of the American people and that should be a sufficient answer to the criticism of southern neighbors. The American policy has brought law and order where it had not been known before. By the safeguarding of life and property it has laid the basis for the development of that economic and political strength which revolution and anarchy otherwise prevent. Finally it has maintained the independence of tottering nations that otherwise would ultimately fall victims to European powers.

It is true serious burdens have been assumed. Our policy leads through untried paths. The problem is not solved. Its solution has only been begun. But of the two alternatives this seems to lead to the 
only constructive solution that will permanently endure.

Inexorable economic laws seem to have decreed that the tropics must be mastered. In Africa and Asia this has been the work of European hands. In the tropics of the New World, America has essayed the task. To this end her policy has been developed. It is a policy of development, not exploitation; of international guardianship, not territorial aggrandizement ; of equal trade for all, and not of exclusive concession. Its fruits are its justification. 


\section{CHAPTER VII}

\section{ENFORCEMENT OF THE DOCTRINE}

$\mathrm{H}^{\mathrm{OR}}$ almost a century the Monroe Doctrine has $F$ been successfully asserted against the great nations of the world. While originally directed against the 'European concert, it has since been successfully invoked against France, Italy, England, Germany, and Japan. All attempts at foreign interference with American affairs which might prove "dangerous to our peace and safety" have been effectually opposed.

This has not been due to the voluntary acceptance of the Monroe Doctrine by other powers as a binding limitation upon their international affairs. Nor has it been due to their belief in the inherent justice or reasonableness of our traditional policy. The evidence shows that in most cases the opposite is true. Bismarck declared the doctrine to be "an international impertinence - a species of arrogance particular to the American and quite inexcusable." In I910 Professor Edward Meyer, in expressing an unfavorable opinion of the doctrine, declared that it "must lead to war as the only solution." Germany's aggressive colonial policy together with her 
peaceful penetration in Brazil were even more significant than the hostile edicts of her writers.

England, who has been friendly to the doctrine when applied to other European powers, has offcially declared that it does not have the binding quality of law and this position has received the support of every European power. It has not been popular in France, and when not received with open hostility it has encountered only indifference in other quarters. The Japanese press, while professing a desire to maintain friendly relations with the United States, was unwilling to admit that the Monroe Doctrine imposed any limitation upon Japan's freedom to acquire land in Magdalena Bay, had she so desired. They considered the doctrine only a declaration of our arbitrary policy and not a principle of law.

Why then has the doctrine been respected by the nations who have denied it both a legal status and the essential elements of justice? Until recent years this question has received little or no attention. It was enough for the average American that it had always been respected. There was a naive confidence in our star of destiny that made investigation useless.

This assuring confidence has been rudely shattered by the outbreak of the World War and the consequent proof of the diplomatic duplicity of Germany, her dream of world dominion, and her 
blind worship of arbitrary power. The far-seeing student of international affairs, who had been pleading for the coordination of a constructive foreign policy with the methods of its enforcements, may now come into his own. The question of why the Monroe Doctrine has been respected has now become a matter of interest and importance to those who would build wisely for the future.

One important factor in the past has been the influence of the European Balance of Power. Professor Latané writes:

It is the only explanation of our having been able to uphold the Monroe Doctrine for so long a time without a resort to force. Some one or more of the European powers would long ago have stepped in and called our bluff, that is, forced us to repudiate the Monroe Doctrine or fight for it, had it not been for the well-grounded fear that as soon' as they became engaged with us some other European power would attack them in the rear.

To support his position he calls attention to the fact that about the time of Seward's ultimatum to Napoleon regarding the withdrawal of French troops from Mexico, the latter was informed of Bismarck's intention to force a war with Austria. In order to be free to deal with the European situation, Napoleon thought it wise to yield to American demands. England yielded to Cleveland's affront over Venezuela largely because of contemporaneous 
events in the Transvaal. The Kaiser's telegram of congratulations to Paul Kruger diverted English wrath from the United States to Germany. In 1902 Germany was restrained from an appeal to combat with the United States over the Venezuelan affair, not only by the fear of the American navy, but by the fact that the British navy lay in the rear. England could not afford to see the European balance disturbed in favor of Germany.

This influence of the European political situation has been further augmented by the commercial interests of Great Britain. Under the Monroe Doctrine, the American republics are assured their independence, which means equal opportunities for British commerce in Latin America. Without the Monroe Doctrine, German colonization with protective tariffs or exclusive concessions would have done irreparable damage to British trade. To these forces should be added the natural sympathy which England has had for the democratic significance of the American doctrine. Professor Latané justly observes "that at any time during the past twenty years Great Britain could have settled all her outstanding difficulties with Germany by agreeing to sacrifice the Monroe Doctrine and give her rival a free hand in South America."

Finally, the Monroe Doctrine has survived because the fruits of American intervention were not sufficiently attractive to compensate for the dangers 
of arousing the enmity of the United States, the opposition of Latin America, and of disturbing the equilibrium of the European balance.

But these forces are by no means static. They afford no assurance of their continuing protection. The Balance of Power has been hopelessly upset by the World War. The events that will follow and their influence upon America, it is impossible to forecast. One thing alone is certain and that is the growth of economic imperialism. It may be along new lines of equal opportunity in backward countries, directed and restrained by a League of Nations, or it may be along the old lines of imperialistic expansion with its dangerous rivalries.

For many years the balance of trade has favored America. We have been changing from an agricultural to a manufacturing nation. Like the industrial countries of Europe, we will eventually be forced to secure new sources of raw material to keep our factories employed, new markets in which to sell our surplus product, and new opportunities for the investment of our surplus wealth. These steps will be essential to the continuance of our industrial growth. In the past our energies have been engrossed in self-exploitation and development and we thus avoided imperialistic rivalries. But that day is past. We must become aggressive competitors for the world's markets. South American trade will take on a new significance to the United 
States, and there will follow a period of spirited competition. European countries, seeking to replenish their wealth wasted in the World War, will be forced to increasingly aggressive policies. The temptation to seek exclusive concessions in Latin America will consistently increase. The unstable conditions in 'Central America particularly will tempt other nations to interfere to protect their property and trade, while the United States will be driven more and more to give to the Monroe Doctrine an economic sigrificance.

An adherence to the Monroe Doctrine under these conditions of stress and strain will bring us into conflict with more vital and fundamental interests of competing powers than we have heretofore encountered. America must be prepared to enforce the doctrine or abandon it. In the present state of public opinion, abandonment would be impossible. To enforce it under the conditions of the future may become a gigantic undertaking. If the Monroe Doctrine should stand as a barrier to the imperialistic needs of European powers, it is not inconceivable that they, goaded by the lash of competition, should find common cause against us. To enforce the doctrine against an European alliance would be a vastly different undertaking from enforcing it against a single power, threatened by the fear of disturbing the European balance.

These considerations, improbable as we may hope 
them to be, require that serious attention be given to the methods of enforcing our national policy. These may be divided into four groups, moral and diplomatic force, legal and judicial methods, military power, and international alliances.

That the Monroe Doctrine has not run counter to prevailing views of international morality has greatly facilitated its maintenance. That it has stood for freedom and equal opportunity rather than exclusive rights and oppressive intervention has made it more difficult for foreign powers to challenge it wantonly. But the World War has taught us that moral restraints will not suffice when they come in conflict with what a state, backed with sufficient force to give promise of success, deems to be its imperial destiny. That moral factors cannot safely be ignored is indicated by the frantic struggle of all the belligerents to prove the justice of their course and by the final triumph of the allies. But it was armies and not arguments that won the victory. Should the doctrine, therefore, ever conflict with what the great powers conceive to be their vital interests, physical, and not moral forces, will prevail.

Perhaps it will be argued that American diplomacy has been successful in the past in maintaining the doctrine with moral force alone. But the doctrine then had not yet come in conflict with fundamental interests of other powers and we enjoyed the 
additional protection afforded by the eagerness of European nations to protect the Balance of Power. For the reasons already indicated we cannot safely rely upon the continuation of those friendly conditions when moral suasion and the potential military force alone sufficed.

The second group of suggestions for maintaining the Monroe Doctrine has to do with international law and arbitration. Since most of the recent threats against the American policy have been connected with efforts of European nations to enforce the financial claims of their nationals against some of the South American republics these suggestions have been primarily concerned with the collection of the obligations. These generally originate in two ways. A foreigner goes to a South American country and invests some capital. A revolution occurs in which his capital is destroyed or perhaps confiscated by arbitrary or irresponsible officials. $\mathrm{He}$ makes up his claim of damages and asks his government to collect it. The other class of claims is loans. Every new government that comes to power through revolutions or otherwise tries to negotiate a loan from foreign capital. When the time of payment arrives it is quite likely that another dictator is in control of the government, who does not care to honor the obligations of the preceding revolutionist. In addition evidence is not wanting that many of these claims are outrageously unfair, 
and that some private ones have been mainly fabrications.

In 1867, Calvo, an eminent Brazilian authority on public law, developed the doctrine which afterward bore his name, that it should be illegal for a nation to use diplomacy or force to back up its citizens in the collection of foreign debts, that a foreigner was entitled to no better protection than is afforded to nationals, and that a nation is not liable for injuries to foreigners occasioned by civil war. A similar though more limited doctrine was urged by the foreign minister of the Argentine Republic, Drago, in 1902, to the effect that the public debt should not "occasion armed intervention nor even the actual occupation of the territory of American nations by a European power." The Drago Doctrine was embodied in The Hague Convention of 1907.

The contracting powers agree not to have recourse to armed force for the recovery of contract debts claimed from the government of one country by the government of another country as being due to its nationals. This undertaking is, however, not applicable when the debtor state refuses or neglects to reply to an offer of arbitration, or, after accepting the offer, prevents any compromis from being agreed on, or, after the arbitration, fails to submit to the award.

This will perhaps facilitate the peaceful settlement of the limited kind of claims covered, and to 
that extent ease up the burden that the American policy has to bear, but at best it covers only a small portion of the possible sources of trouble.

To meet the many other classes of claims, Philip M. Brown, formerly minister to Honduras, has suggested the importance of creating a body of international law to control the mutual relation of the republics of this continent.

It is highly desirable, for example, that there should be an agreement defining the rights of international creditors, and prescribing the precise mode of procedure to protect these rights. There should be an international law concerning claims founded on governmental concessions granted to aliens, and international law defining the rights of aliens in times of domestic revolt, and an international law of torts to determine definitely the rights of aliens in claims for damages on account of alleged injuries at the hands of foreign states. Such questions of moment should never be left to the arbitrary caprice of governments; nor should they be carelessly submitted to arbitration without any previous agreement as to the law to be applied.

This would tend to minimize friction and help pave the way for better Pan-American relations. Two questions would still be open as to whether the Latin American republics have reached the point of development where such an arrangement could be made and efficiently administered, and whether it would be satisfactory to foreign cred- 
itors. Obviously this suggestion would only protect American interests in so far as it satisfied the European powers. The great bulk of the burden of protecting America from future foreign interference would still fall upon the United States. While this excellent scheme may afford us a valuable instrument with which to meet some of the problems presented by the more recent aspects of the Monroe Doctrine it does not afford us an escape from the duty of its ultimate defense.

Some writers have suggested arbitration as an effective safeguard for our foreign policy. But arbitration works either through the compromise of conflicting claims or by the application of principles of law. If the Monroe Doctrine were a principle of international law this might be a feasible scheme. But since it is not, any dispute involving it, if arbitrated, would come to a compromise, which would indicate only a willingness to abandon it, partially at least, and could not be considered as a method of enforcement. Should the time come when its piecemeal abandonment would seem wise, arbitration might be usefully employed.

The third suggested method of enforcement is the military power of the United States. As we triumphantly emerge from the World War, this method makes a strong appeal to the American imagination. Our new-found power is not without its insidious temptation. With the European na- 
tions weakened by four years of gigantic struggle, the task of defending the Monroe Doctrine by military power seems both feasible and alluring. But backed by the growing necessity for foreign markets and for an economic imperialism, it might become a menace to the altruistic aspects of American policy. Moreover, the rehabilitation of European nations would probably take place with marvelous rapidity. The quick recovery of France from the tragic defeat of 1870 should teach us the danger of relying upon the permanent weakness of nations reduced by the strain of war.

Nor must it be supposed that this method would bring us into conflict with isolated nations only. Should the Monroe Doctrine take on an increasing economic significance, should it become the barrier to European exploitation, and should the imperialistic rivalries between the United States and Europe develop to their logical conclusion, it would be to the interest of European powers to unite against the policy that impeded them. The defense of Latin America against such a concert of power would involve consequences of the most hazardous character. And yet any program of military enforcement which contemplated less would not afford adequate security for the future. Since it is extremely unlikely that the American public would build and maintain in times of peace a military establishment of sufficient magnitude to defend Latin America 
against such a possible alliance, military power alone would seem to offer at best a hazardous and uncertain guarantee.

Finally, it has been suggested that some form of international alliance would afford the desired methods of enforcement. John Barrett, Director General of the Pan-American Union, has made a persuasive plea in favor of substituting for the Monroe Doctrine a "Pan-American Policy," a policy which would be the joint property of all the Latin American states for their mutual benefit and protection. Others have suggested a more limited American alliance with only the United States and Argentina, Brazil, and Chile. The main benefits of such alliances would be to relieve America and the Monroe Doctrine of the suspicion of territorial aggrandizement, to secure the confidence and sympathetic cooperation of Latin America, and by the union of all their forces to make more effective their opposition to any interference by foreign powers. This would facilitate the solution of all inter-American questions and especially those arising out of the necessity of intervention in the interests of law and order in the Caribbean countries. To substitute joint action for the individual action of the United States in such cases would restore confidence in the good faith of the United States and tend to quiet down the opposition of the state involved The favorable effect upon the public 
opinion of Latin America, of our acceptance of the A B C mediation in regard to Mexico, was truly significant.

However such alliances bring problems that are not easily solved. Since the overwhelming burden of enforcing the policy would still rest upon the United States (although doubtless the A B C powers could render material assistance) would the United States be willing to have that policy formulated, developed, and applied by a body in which she did not have the deciding voice? Could the United States afford to abandon her liberty of action in regard to a policy which experience has shown to be vital to her peace and safety? Doubtless it would be the part of wisdom for us to seek the cooperation of these powers, whenever possible, but to abandon liberty of action with regard to fundamental policy would be giving hostages to fate and would not relieve us from the ultimate burden of defending our policy from foreign encroachment.

One other suggestion remains and that is the League of Nations, adopted in the Paris Conference. Since the future menace to the Monroe Doctrine consists in the imperialistic needs and rivalries of the great powers of the world the suggestion is made that instead of trying to oppose them, we join with them in an organization by which there might possibly be secured to each nation its fair share of commercial opportunities through peace- 
ful adjustment, and where the combined forces of all would guarantee the peace and safety of each. This might be so arranged as to secure to the American republics protection against improper intervention, a protection not guaranteed by the United States alone but by the most powerful nations of the world. If the members of the league should abide by their agreement this protection would be complete and if they should fail, the United States would again be free to defend her national policy. The League-of-Nations idea would thus seem to offer some hope of security. Its peculiar relation to the Monroe Doctrine will be considered in the succeeding chapter.

It would seem therefore that the enforcement of the Monroe Doctrine in the past has been easily accomplished because of the influence of the European Balance of Power and the lack of sufficient incentive to compel a nation to face American opposition here and jealous rivalries in Europe. With the tremendous commercial competition that will develop as the nations seek to restore their wealth wasted in four long years of war, a great incentive to acquire footholds in Central America and the Caribbean will be afforded. A foreign alliance to enforce such interests, while improbable, is not impossible. Against such opposition the forces of diplomacy could not prevail. Arbitration would only lead to compromise. Military defense 
to be adequate would have to be gigantic. PanAmerican alliances, while smoothing out interAmerican problems, would not aid decisively against foreign intervention. But a League of Nations, if successful, might afford an adequate defense. Is it not, then, our best hope of permanent security for our Latin neighbors and therefore a practicable guarantee of the "peace and safety" of America? 


\section{CHAPTER VIII}

WORLD WAR AND THE LEAGUE OF NATIONS

$7 \mathrm{HE}$ outbreak of the World War in I9I4 left 1 America shocked, incredulous, and impatient. With our traditional ignorance and indifference regarding world affairs, we had come to regard a great European conflict as no longer probable. We resented the war as a wicked and unwarranted interference with the peace and happiness of the world. As a people we denounced the invasion of Belgium, anathematized Germany for her part in the beginning of the struggle, clung tenaciously to our theory of isolation, and accepted the government's traditional policy of neutrality.

President Wilson's proclamation was received with widespread approval. It is true it was subsequently made the subject of much ex post facto criticism by those upon whom "hind sight" had conferred superior vision. But at the time the policy of neutrality was the inevitable product of our American policy, our customary attitude toward European conflicts, our peace-loving traditions, and our blind, naive confidence in the safety and permanence of our isolation. Any other policy would have 
been almost inconceivable and at that time would have encountered tremendous opposition.

But America soon found the rôle of the neutral both difficult and hazardous. When European nations engaged in a great and bitter war, our traditional isolation seemed mainly a tradition. British supremacy on the sea cut off Germany's trade with neutrals. The extension of the theory of continuous voyage to apply to goods shipped to neutral territory, contiguous to Germany, and the enlargement of the lists of contraband, made Germany's isolation almost complete. The British policies, especially the extension of the theory of continuous voyage, were of doubtful legality and America protested, but our protest was weakened by our own extension of the doctrine in the Civil War. Moreover, England conducted herself with a scrupulous regard for human life, subjecting herself only to pecuniary claims which could be amply met at the conclusion of the conflict.

Germany retaliated with her submarine campaign, first directed mainly against enemy shipping and only incidentally against neutrals, and finally by the decree of February, 19I7, directed against all shipping on a zone extending far into the high seas. Ships within these zones were sunk without regard to the legal rights of the owners, crew, or passengers. American shipping and American citizens were thus ruthlessly destroyed in utter defiance of 


\section{World War and the League of Nations 129}

the plain, unquestioned rules of international law. America uttered repeated protests, but to no avail.

In addition, Germany filled our country with secret agents who sought to break up our munitions business by strikes, sabotage, and the lawless destruction of life and property. The Austrian ambassador and the German military and naval attachés were recalled for participating in these criminal enterprises. The Zimmermann note to the German minister in Mexico, suggesting an alliance with Mexico and Japan against the United States, together with the resumption of "ruthless submarine warfare" brought matters to a climax and on April 2, 1917, President Wilson appeared before Congress and asked for a declaration of war against the Imperial German Government.

The wanton violation of American rights was the immediate and legal cause for our abandonment of neutrality and isolation and our entering the world conflict. But back of these matters were more fundamental considerations that were slowly taking form in the American mind. While we had honestly and effectively observed the legal obligations of our neutrality, our sympathy was increasingly with the allies. The sinister character of German diplomacy, her worship of brutal, arbitrary power, her savage methods of warfare, her absolute disdain of every consideration of honor, decency, and law, together with her gigantic military power, 
began to impress the American mind, that despite our "splendid isolation," such a power, if victorious, would menace not only the freedom of Europe but the democracies of the world. For there was dawning in American consciousness the understanding that the war was not merely a conflict between the contending nations but a life and death struggle between the democracies of Europe and the forces of autocratic power. At last America realized that her isolation had disappeared, that she was a part of the civilization of the world, and that she dared not evade its obligations. (As our statesmen of 1823 realized that the independence and security of the newly founded republics of this hemisphere were essential to our "peace and safety," so today America has found that her future is inseparably linked with the destinies of democracy and the civilization of the world.

Inventive genius has annihilated space and time and the Atlantic no longer affords to the democracy of the Americas effective barriers against the wars, intrigues, and autocracies of Europe. We clung desperately to the idea of isolation, but we found it a delusive hope. We found ourselves merged into a new world order where aloofness was neither possible nor worthy. We found ourselves confronted with new world problems that challenged our statesmanship and tested our devotion to the cause of liberty. 
World War and the League of Nations 131

These were the underlying forces that gave to America's part in the great war the spiritual power of the crusader's zeal. It was the dawning realization that this was a war to end war, a conflict to make the world safe for democracy, a struggle to overthrow forever the menace of wicked, arbitrary power, that aroused America, that inspired our people, and gave to our valiant soldiers their courage and resistless power.

These were the spiritual forces that found such eloquent expression in the words of President Wilson when he asked Congress to declare war against Germany.

Neutrality is no longer feasible or desirable where the peace of the world is involved and the freedom of its peoples, and the menace to that peace and freedom lies in the existence of autocratic governments backed by organized force which is controlled wholly by their will not by the will of their people.

We are now about to accept gauge of battle with this natural foe to liberty and shall, if necessary, spend the whole force of the nation to check and nullify its pretensions and its power. . . . The world must be made safe for democracy. Its peace must be planted upon the tested foundations of political liberty. We have no selfish ends to serve. We desire no conquest, no dominion. We seek no indemnities for ourselves, no material compensation for the sacrifices we shall freely make.

It is a fearful thing to lead this great peaceful people into war, into the most terrible and 
disastrous of all wars, civilization itself seeming to be in the balance. But the right is more precious than peace, and we shall fight for the things which we have always carried nearest our hearts - for democracy, for the right of those who submit to authority to have a voice in their own governments, for the rights and liberties of small nations, for a universal dominion of right by such a concert of free peoples as shall bring peace and safety to all nations and make the world itself at last free.

The instrumentality through which President Wilson hoped to translate this lofty vision into accomplished fact was the League of Nations. From the early part of 1916 his public utterances began to deal with the problems of international organization where "coercion shall be summoned not to the service of political ambition or selfish hostility, but to the service of a common order, a common justice, and a common peace." In his famous Fourteen Points the last one declared for "A general association of nations must be formed under specific covenants for the purpose of affording mutual guarantees of political independence and territorial integrity to great and small states alike." In September, 19I8, he declared the League of Nations to be an "indispensable instrumentality" to the peace and security of the world, and that the consitution of the league " must be a part, is in a sense the most essential part, of the peace settlement itself." 


\section{World War and the League of Nations I33}

To this end President Wilson labored at the Paris Peace Conference with the result that the first draft of the covenant of a League of Nations was completed and given to the public February I4, 1919. A second draft with some important changes was adopted by the conference, April 28, I9I9.

According to the terms of the covenant, first proposed, the nations will create a body of delegates, in which each member shall have one vote, and an executive council composed of one representative each from the United States, the British Empire, France, Italy, Japan, and four other nations to be determined by the body of delegates. The executive council shall formulate plans for reduction of armaments and secure their voluntary adoption by the members of the league. When once agreed upon, the amount of armaments prescribed shall not be exceeded by members of the league without the permission of the executive council. A permanent commission is to be established to advise the league on the execution of these provisions. A permanent court of international justice is to be established to which members may refer their disputes. The members jointly engage to respect and preserve as against external aggression, the territorial and political security of each. They furthermore agree that in no case will they resort to war until first submitting the case to arbitration, if they regard it 
as justiciable, or to inquiry by the executive council and until three months after the award or recommendation, and that they will not then resort to war if the opposing nation complies with the arbitral award or with the recommendation of the executive council, provided, that the recommendations of the council be unanimously agreed to by the members of the council other than the parties to the dispute.

Should any nation make war contrary to the foregoing provisions it shall be deemed to have committed an act of war against all the other members, who agree to sever all diplomatic, commercial, and financial relations with the offending state. In such cases it will be the duty of the executive council to recommend what military or naval forces the nations should use to protect the covenants of the league. The power of the council in this respect is limited to mere recommendation.

Provision is made for the control of the territory and colonies, not yet ready for self-government, which were under the jurisdiction of the Central Powers, by a system of mandatories responsible to the league, and which will secure equal opportunities for the trade and commerce of other members of the league.

This proposed covenant encountered much hostile opposition based, among other things, upon its alleged conflict with the Monroe Doctrine. It is only 
with this class of criticisms that we are here concerned. These critics contend that our adherence to the League of Nations would involve the impairment or abandonment of the Monroe Doctrine in two respects. In the first place it would violate our policy of isolation and involve us in an entangling alliance. In the second place it would sacrifice the Monroe Doctrine itself or at least our freedom of action in its enforcement.

In considering the first objection it should be observed that the Doctrine of Isolation with its opposition to entangling alliances cannot properly be said to be a part of the Monroe Doctrine. It received its most authoritative expression in Washington's Farewell Address, but those who now rely upon it seem to ignore that Washington did not regard it as an eternal maxim but rather a temporary measure " to gain time to our country to settle and mature its yet recent institutions, and to progress without interruption to that degree of strength and consistency which is necessary to give it, humanly speaking, the command of its own fortunes." The Doctrine of Isolation was adopted as the best means, under the then existing circumstances, to safeguard the young republic during the period of its infancy. While Monroe sought to gain strength for his doctrine by emphasizing our policy of isolation, the two policies were independent both in their origin and nature. 
Nevertheless we may well inquire if our becoming a member of the League of Nations would involve a dangerous or unwarranted departure from our policy of isolation. When that policy was formulated we were a weak and struggling republic, with a long and undefended coast line. The isolation of the New World from autocracies and conflicts of the Old was an undisputed fact. Engrossed in the conquest and development of a great continent, we had little cause for conflict with the interests of Europe. The Atlantic seemed a sufficient barrier against European powers. Our isolation seemed complete.

But today the conditions that made the policy of isolation essential to our defense have disappeared. Modern science has annihilated space and time. America has long since passed the stage of self-sufficiency. Our commerce is found upon every sea. Our competition is felt in every market. Our politicians still render lip service to the policy, but our statesmen in dealing with actual problems, have ignored it. It is considerably over a half a century since Perry's expedition to Japan announced to the world American aggressive interest in the Eastern Hemisphere. We have participated in many European conferences dealing with nonAmerican affairs. We have acquired islands in the Far Pacific. When European powers contemplated interference with Chinese integrity, America played 
a conspicuous part because her interests were involved. We have played a worthy part in the two Hague conferences. When the peace of Europe was threatened over the Moroccan question we sent representatives to the conference at Algeciras, and there is authority for the statement that America played more than a passing rôle, although the question at issue was largely the maintenance of the European balance. It is true that the Senate attached to its ratification of the treaty there adopted, a declaration that the sole purpose of America's participation was the protection of our citizens and commerce, the desire to aid in the removal of friction that might menace the peace between the powers concerned and "without' purpose to depart from the traditional American foreign policy which forbids participation by the United States in the settlement of political questions which are entirely European in their scope." There can be little doubt, however, that the motives of President Roosevelt and Secretary of State Root were essentially political, that they recognized that our isolation had disappeared, that a general European war would affect the most fundamental interests of America, and that it was the part of vision, courage, and common sense to recognize the patent facts, and to grapple with the European problem in order that America might be spared the menace of a European war. The absolute soundness of this 
view has been amply demonstrated in the World War. In spite of our vaunted isolation, the peaceful aspirations of our people, and the marvelous patience of our President, our most sacred interests were vitally affected and our entrance into the tragic conflict became inevitable. Amerira should now know that she can no longer view with idle equanimity the devastating quarrels of Europe, for great European wars have now become our own.

With these facts in mind, the American proponents of the League of Nations contend that they - are merely following the vital interests of America, wherever they may lead, in the hope that at least some wars may be averted and that America may be spared the repetition of the recent tragedy. They have ample precedent in the examples cited above, and the same spirit of national self-defense that prompted Washington to take advantage of the facts of isolation to safeguard, temporarily, the interest of America, would seem to demand, with equal force, the departure from that doctrine when the facts of isolation have disappeared and our vital interests have become so intimately concerned with the quarrels of Europe. Washington wanted isolation to spare America the scourge of war. Because of modern conditions, the same object can only be attained by international organization. The spirit, courage, and desire of Washington remain, only the methods of their accomplishment are changed. In 
fact, has not the time arrived, to. which Washington looked forward, when America has attained "that degree of strength and consistency which is necessary to give it, humanly speaking, the command of its own fortunes," and when she may, therefore, courageously undertake to play a worthy part in grappling with the vital problems of the world?

The phrase most frequently invoked against the League of Nations is the pronouncement of Jefferson against "entangling alliances." This raises the question as to whether the proposed League of Nations is the kind of an alliance with which Jefferson was familiar and against which he warned his countrymen. It is clear that the alliances to which Jefferson referred were secret alliances, either between ruling families or European powers, involving assurance of military participation in the many wars, either for the purpose of maintaining some ruling family upon its throne or to adjust the everchanging Balance of Power. Obviously this does not correspond to the League of Nations which is directed against secret diplomacy and intrigue and which seeks to achieve peace, not by a Balance of Power, but by organized effort among all the enlightened nations of the world. In advocating a League of Nations, President Wilson declared that he was, avoid entangling alliances which would draw them into 
competitions of power, catch them in a net of intrigue and selfish rivalry, and disturb their own affairs with influences intruded from without. There is no entangling alliance in a concert of power. When all unite to act in the same sense and with the same purpose, all act in the common interest and are free to live their own lives under a common protection.

The old alliances were formed for the purpose of waging war, whereas the League of Nations has as its fundamental aim the securing of peace. As abstention from entangling alliances tended to safeguard America from the evils of war in the days of Jefferson, so the League of Nations seems to afford the only hope of peace amidst the conditions of today.

But it has been contended that under Article x, in which the members of the league agree to respect and preserve against external aggression, the political independence and territorial integrity of all the members of the league, and in which the executive council is authorized to advise how this obligation shall be fulfilled, the United States may be entangling itself in the European controversies of the future. The same contention has been advanced in connection with Article xvI which authorizes the executive council to recommend what military and naval forces the members of the league shall contribute for the protection of the league covenants, while others have feared that under 
World War and the League of Nations I4I

Article xIx dealing with mandatories (Article XxII of the revised covenant) the United States might become involved in foreign politics by being compelled to accept mandatories for colonies in remote portions of the globe.

These fears and contentions have little basis in fact, since in the first two cases the power of the executive council is only to recommend or advise, and furthermore, since in the revised covenant Article $\mathrm{v}$ expressly provides that the decisions of the council shall require the agreement of all the members of the league represented at the meeting, and Article Xxil of the revised covenant provides that mandatories are to be given only to those willing to accept them. Since the United States is a member of the executive council she cannot even be advised by that body without her own consent. It is true that under Article $\mathrm{x}$, it becomes the duty of the United States to respect and preserve the integrity of the members of the league, she being the sole judge of the nature and extent of the obligation: The difference, however, between this mutual undertaking for self-protection and an entangling alliance would appear obvious.

It would seem therefore that so much of the case against the League of Nations as rests upon the Doctrine of Isolation is not persuasive or convincing. The facts of isolation have long since disappeared. Adherence to a League of Nations would 
not, therefore, be the abolition of isolation but the mere recognition of real conditions as they exist. The league represents an effort to secure by constructive statesmanship that immunity from war which our old policy so signally failed to provide in the recent conflict. It is an effort to found a constructive peace policy upon the realities of today as distinguished from the ostrich-like naivete of those who seek to base great national policies upon effete theories of isolation which are negatived by the most obvious facts of modern life. As former President Taft has so wisely observed, the recent war has demonstrated that the "so-called policy against entangling alliances" is "inconsistent with the needs of this nation and the needs of the world to secure the peaceful future of both."

But will American membership in the proposed League of Nations mean the abandonment of the Monroe Doctrine or the loss of our present independence of action in regard to its enforcement?

In the first place is the doctrine as expounded by its author - a mere declaration against European intervention in South America to restore the new republics to Spanish dominion - placed in jeopardy by the League of Nations? We had recognized the new republics and we regarded any interference with their independence as the "manifestation of an unfriendly disposition towards the Unied States." So far as the original doctrine is con- 
World War and the League of Nations 143

cerned it amounts to nothing more than America's guaranteeing the independence of Latin American governments against European intervention. Article $\mathrm{x}$ of the constitution of the proposed league binds the contracting parties to respect and preserve as against external aggression, the territorial integrity and existing political independence of all state members of the league. Most of the Latin American republics are to be members of the league, and they will thus enjoy a greater security against European intervention than could possibly be afforded by America alone. In the preceding chapter, the possible difficulties of enforcing the Monroe Doctrine against the world powers were found to be tremendous, while under the league the security afforded will be vastly augmented and the burden of its enforcement will be shared by the nations of the world. So far, therefore, as the Monroe Doctrine safeguards our national interests by protecting South America from forcible European intervention, the League of Nations makes us doubly secure. To those who argue that the league may not work, that the nations will not abide by their covenants, the answer is easy and direct. If they do not abide by their agreement then America is not bound by hers and will be free to defend the doctrine as she may desire.

In the second place what will be the effect of the League of Nations upon the policy of American pro- 
tectorates in the Caribbean and in Central America? We have intervened in these cases because these states did not meet their obligations to European countries. We had to take an active hand in enforcing these obligations or see it done by European powers. Since the latter might easily lead to permanent occupation or aggression, America chose to assume the responsibility.

Since such protectorates, when not voluntarily accepted, are a violation of the political independence of the protected state, America would be prevented from the forcible inauguration of such a policy if the state involved were a member of the league. But at the same time the reason for our intervention, viz., the prevention of European aggression in America, would have been removed by the operation of the same restriction upon European powers. So far as these countries were members of the league, our policy of protectorates would become unnecessary to safeguard us against European aggression in this hemisphere. Our defense of our interest would rest in this case, not in American force alone, but in the combined force of the free governments of the world. This would give to Latin America lasting assurance against the fear of American territorial aggrandizement, which would be a mighty step towards better political and commercial relations with our southern neighbors. 


\section{World War and the League of Nations 145}

Since, however, some of the unstable nations in the Caribbean regions such as San Domingo and Mexico are not now to become members of the league, they are not entitled to the protection of Article $\mathrm{x}$ above referred to. In case a European power were pressing claims against such a state, the nations agree that such a state shall be invited to accept the obligations of membership in the league for the purpose of the dispute.

This would throw the dispute into the executive council for inquiry into the merits of the controversy and for recommendation. America would be represented on the executive council. If the recommendation were unanimous, neither nation would be free to make war unless the other refused to abide by the decision. If it was not unanimous, then either nation would be free to fight. Thus it appears that the right of making war might be denied in such a case by the unanimous action of the council in which America would have a vote. But suppose the two nations should submit their dispute to arbitration, instead of to the executive council, and thus agree to be bound by its decision? It has been suggested that a decision against the American country might involve an invasion of the Monroe Doctrine. But the doctrine has never set America up as the sole dictator in such disputes. At the most it has denied that rôle to European states. In I895 in the controversy with England, 
and in 1903 in the dispute with Germany, all we asked for in the name of the Monroe Doctrine was that the disputes be referred to arbitration. Since the league provides for this very remedy in this class of cases it is difficult to see why in such controversies the league will not give additional, rather than less protection, to the American interests protected by the doctrine.

Suppose, however, that the dispute was not referred to arbitration and the executive council could not reach a unanimous decision, then the nations would be free to fight. If the war resulted in the defeat of the American state and it was thereby annexed as a colony by the victorious power, would the United States be bound to accept the result? If so, then the Monroe Doctrine would be violated and America would be helpless. But under the league, while America could not at once make war against the offending European power, she could refer the matter to the executive council for inquiry and recommendation. If all the other members of the council, save those from America and the offending country, should make a unanimous recommendation against America's contention, with which the other power complied, then the United States would be in honor bound not to make war against the European state. If no unanimous decision were reached, we would be free to fight at the expiration of three months. 
World War and the League of Nations 147

Thus it appears that if a European power gets into a controversy with an American state not a member of the league, and the American state should refuse to abide by the unanimous decision of the executive council, or that the council should not be able to reach such a decision, and the European power should acquire by conquest territory in America, and the executive council by unanimous decision should overrule America's protest, a violation of the Monroe Doctrine might take place which America would be powerless to prevent. The limitations and conditions to this eventuality are so numerous and improbable that it scarcely deserves serious consideration. The experience of international conferences in reaching unanimous decisions where the deliberate effort has been made would seem to indicate the extreme improbability of a dispute arising between one of America's backward countries and a European power which such a body as the executive council could not dispose of by unanimous decision, thus foreclosing the possibility of war. Nevertheless the theoretical possibility remains.

The third phase of the Monroe Doctrine that may be affected by the league is that which opposes the voluntary transfer of any American territory to any European power. There is nothing in the league to prevent such a transfer unless it be Article XXI of the revised covenant discussed below. If, for in- 
stance, Germany should seek to acquire by peaceful and lawful means a naval base in Central America, the league would afford no hindrance. On the other hand, before the United States could make war to prevent it, we would be bound to submit the matter to the executive council and to wait until three months after its decision, and we could not then make war if the council ruled unanimously against us.

For this reason the suggestion was made by members of the Senate and others that a specific provision be inserted in the league constitution that no foreign power should acquire territory in any manner in the American continent or adjacent thereto. This would take care also of the possibility of a European power's securing American territory by conquest as discussed above. This particular suggestion was not adopted but it is conceivably covered by Article xxI. If the league affords the protection against war that it is designed to achieve, the importance of the phase of the Monroe Doctrine under discussion will speedily disappear as it is mainly a matter of military or naval strategy.

The fourth aspect of the Monroe Doctrine to be considered in relation to the League of Nations is that phase which is most indefinite and which is perhaps best described as the United States hegemony in Central and South America. It is this position 
of assumed superiority that.draws forth the bitter criticism of Latin America. It is its very indefiniteness that gives them ground for uneasiness. The Mexican War, the Panama incident, certain senatorial pronouncements, and newspaper policies regarding our duty and destiny in Mexico have given some reason to their fears. "From the Rio Grande to Panama" has a certain rhythmic cadence that they feel is too typically American.

It seems clear that it is this indefinite power to wield a strong arm in American affairs that some of our statesmen are trying to preserve by the amendment to the League of Nations that expressly preserves the Monroe Doctrine. As will appear later, it is extremely doubtful if the amendment adopted will have that effect. It is significant that South America opposed this amendment with practical unanimity. Because of its uncertainty it met with opposition among European countries, and encountered opposition even in the United States. Former President Taft, while favoring a recognition of the Monroe Doctrine in the covenant, rebuked those who seek to preserve the doctrine as a shield for arbitrary interference with our neighboring states.

Those who would seek to enforce a Monroe Doctrine which makes the Western Hemisphere our own preserve in which we may impose our sovereign will on the will of other countries in their own interest, be- 
cause, indeed, we have done that in the past, should not be sustained.

Perhaps it is significant that those who claim that the league will interfere with America's handling of inter-American problems have not designated just what specific policies they contemplate. Certainly it is difficult to foresee any legitimate policy, not based purely upon the Prussian theory of conquest, that would be seriously hampered. Most of this discussion centers about Mexico, and for the time being Mexico is not to be a member of the league and not entitled, therefore, to its protection. To those who accept the Prussian philosophy of forcible annexation by the superior state, the league affords an effective bar, except as against non-member states, for all nations covenant to respect and preserve the political independence of member states.

If, however, it becomes necessary again to use hostile measures to compel Mexico to respect the legal rights of the United States or her nationals, it is difficult to see how membership in the league would hamper legitimate measures, supposing that Mexico should become a member. The United States would refer her case to the executive council. The nations in the executive council would have the same interest as the United States in preserving life and property in Mexico and would undoubtedly make recommendations accordingly. If Mexico re- 
World War and the League of Nations I5I

fused, America would be free to make war or intervene. If the temporary policing or occupation of the country were deemed essential, the executive council could recommend it and the United States could enter with a mandate from the league, should she desire. Intervention under such auspices, with the backing of the league and its assurances of good faith, would make opposition much more difficult, if not impossible. It would set at rest the fears and suspicions of Latin America and make for that spirit of mutual understanding and sympathy which has been the object of the most contınuous solicitude of American statesmen and business men for many years. What is true here would be equally true of the unsettled countries of Central and South America and the Caribbean region. Should it become necessary again for America to assume responsibility for the fiscal relations, or for the law and order of the turbulent republics of the Caribbean, the procedure here suggested would seem the wisest and the safest.

To insure the continuation of cordial Pan-American relations former President Taft and others have recommended that purely American questions should be settled by American nations with machinery similar to that provided for the league. There seemed to be no particular opposition to such suggestion but its incorporation in the revised league covenant was not secured. There is nothing how- 
ever to prevent the executive council from recommending such action when the occasion may arise.

Because of the various objections based on the different aspects of the Monroe Doctrine, the American delegation at the Paris Conference secured the irsertion in the revised covenant of Article $\mathrm{XxI}$ which provides that nothing in the covenant shall be deemed to affect the validity of international engagements such as treaties of arbitration or regional understandings like the Monroe Doctrine for securing the maintenance of peace. The significance of this provision is not obvious, because of the uncertainty and indefiniteness which characterizes the meaning of the doctrine.

Does it mean to preserve only the fundamental principles of the original doctrine? Will this prevent the peaceful cession of American territory to foreign powers? Will it safeguard our policy of protectorates in the Caribbean? Will it grant America unlimited freedom in dealing with Central and South America? So eminent an authority as Elihu Root, speaking in I9I4, declared that the policy of protectorates and the claims of superiority over Latin America had nothing to do with the Monroe Doctrine, although he did think that the doctrine included opposition to the peaceful cession of American territory to foreign powers.

Some light is thrown upon it by the commentary on Article XXI, issued by the British delegation to 
the Paris Conference, which declared that the Monroe Doctrine and similar understandings not instruments of national ambition but guarantees of peace. The origin of the Monroe Doctrine is well known. It was proclaimed in 1823 to prevent America from becoming a theater for intrigues of European absolutism. At first a principle of American foreign policy, it has become an international understanding, and it is not illegitimate for the people of the United States to say that the covenant should recognize that fact. In its essence it is consistent with the spirit of the covenant, and, indeed, the principles of the league as expressed in Article $x$ represent the extension to the whole world of the principles of this doctrine, while, should any dispute as to the meaning of the latter ever arise between the American and European powers, the league is there to settle it.

It would appear from this that the conference had in mind only the original doctrine, with the mere possibility of including the corollary against peaceful cession, and with the understanding that disputes between America and European powers over the meaning of the doctrine, should be determined by the league. To meet this situation the foreign relations committee has proposed a reservation which is intended to preserve to the United States its traditional policy in regard to American affairs. It is meeting with opposition and its final adoption is unoertain. 
In spite of such a restricted definition of the Monroe Doctrine as used in the covenant, it would seem, from the preceding discussion, that the League of Nations instead of being an impediment to America may become a very valuable asset as a guarantor of her good faith in those instances where her legitimate interests may require intervention or the exercise of force.

If America should refuse to become a member of the League of Nations, it seems inevitable that her refusal would be the signal for a great European alliance. America, being the only great nation whose vitality has not been wasted in four years of war, because of her very power and strength, would be its natural foe. This would be accentuated by the stress of the commercial wars that are bound to come. The financial necessity of armament reduction and the exigencies of trade would tend to make the European alliance all inclusive as against America, rather than divided into a balance of European power between alliances and ententes. If there is to be any real menace to the Monroe Doctrine it would seem to be in such combination of European powers. Political dominion in Central America and the Caribbean, with its possibilities for exclusive grants and arbitrary control of markets, will be most alluring in the bitter trade wars that are ahead. From these wars there seems to be no method of escape. 


\section{World War and the League of Nations I55}

As compared with this possible eventuality, a League of Nations where these same European nations guaranteed the territorial integrity and political independence of Latin American states, which would make an anti-American alliance impossible and undesirable, and which would tend to smooth out the problems and the friction created by the occasional necessary intervention in the more unstable countries, would seem eminently preferable. With America in the League of Nations, a European alliance against us seems quite impossible since absolute financial and political necessity will compel European nations to scale down their armaments to the bare needs of national defense which will be vastly lower if America is a party to the program of disarmament, and they can rely upon the league for their defense against the possible menace of America's tremendous power.

The Monroe Doctrine was essentially a measure of self-defense, with an idealistic aspect that secured for it unusual popular support. It seemed that the "peace and safety" of the United States could be best secured by preserving the struggling democracies of a hemisphere. It was a bold and daring step that required courage, vision, and common sense. Almost a century has elapsed. With the changed conditions our isolation has disappeared. We have seen that a great European war, over European interests, cannot be fought without 
involving the vital interests of America. We have learned that great European wars have become our own. We now know that the only way to safeguard our "peace and safety" for the future is to provide for the "peace and safety" of the world. The only way for America to avoid the scourge of another war is to see that another war does not occur. The League of Nations seems the only means available for the achievement of that worthy aim. Its details may be so arranged that it involves no necessary or inherent conflict with the vital principles of our established doctrine. It is true, all its implications cannot now be foreseen. Like the Monroe Doctrine it will lead through untried paths, across uncharted seas. But as a measure of self-defense, its necessity cannot well be denied. Like the doctrine that it amplifies, it is a bold and daring effort at national self-defense, but one which also faithfully articulates the spiritual aspirations of American democracy. 


\section{CHAPTER IX}

THE MONROE DOCTRINE OF THE FUTURE

A NATHEMATIZED by its foes as passionately $A$ as it is eulogized by its friends, arousing suspicion, hate, or approbation in varying degrees among our Latin neighbors, meeting with friendly tolerance, growing envy, or absolute hostility among foreign critics, the Monroe Doctrine has become the storm center of our foreign politics in recent years. It has been denounced as an "obsolete shibboleth," and ignis fatuus, and our devotion to it as "mere slavery to rhetoric and sentiment."

On the other hand it has been called the "second Declaration of Independence." By the great majority of the people it is regarded with religious veneration and President Cleveland declared that it " cannot become obsolete while our republic endures." Popular audiences, amidst tremendous enthusiasm, declare their willingness to defend the doctrine with their lives, but they could not possibly define its content or explain its meaning. The opposition to the League of Nations in America has turned largely upor. its effect upon this cardinal feature of our foreign policy. 
American criticism of the Monroe Doctrine has come largely from academic men, while statesmen and politicians have been almost unanimous in its support. In I9I4, George H. Blakeslee submitted a questionnaire to the lecturers on international law and diplomacy in American colleges and universities. The results showed that in the judgment of these men, first, the present status of the Monroe Doctrine was unsatisfactory both as to its indefiniteness and its sole interpretation and enforcement by America; second, the doctrine should not be abandoned; third, it should be made more definite and the United States should share with the more stable South American powers the responsibility of enforcing the doctrine either by complete cooperation with them, abandonment of the policy south of the equator, or abandonment so far as the stable states are concerned. The same questionnaire sent to a selected list of newspapers and periodicals brought practically the same results.

An analysis of the criticism coming from the United States and from Latin American countries as well, shows a confusion of ideas as to the meaning of the doctrine, and an underlying suspicion and fear due largely to the sweeping generalizations that our public men have been prone to make in regard to it. Some of the demands for its abandonment, when closely analyzed, show no hostility to its fundamental principle but are really directed 


\section{The Monroe Doctrine of the Future I59}

against its name as a useless bugaboo, or against some tactless assertion of its power, or against the method of its inforcement.

In searching for the Monroe Doctrine of the future, therefore, it becomes essential at the outset to state its fundamental principle and the various aspects that have been developed on the several occasions of its assertion. The original doctrine as enunciated by Monroe was a twofold declaration, first, that "the American continents . . . . are henceforth not to be considered as subjects for future colonization by any European powers," and second, that "we could not view any interposition for the purpose of oppressing" the independent governments of this hemisphere, "or controlling in any other manner their destiny, by any European power, in any other light than as the manifestation of an unfriendly disposition towards the United States." With these two fundamental conceptions, the former of which is no longer a matter of practical concern, three great principles of foreign policy have been associated and generally sponsored under the name of the Monroe Doctrine. The first principle was enunciated by President Polk when he declared that the voluntary cession of American territory to a European power was dangerous. Later Grant asserted "that hereafter no territory on this continent shall be regarded as subject of transfer to a European power." Former Secretary of State 
Root, while denying that the original doctrine has been otherwise altered or amended, has declared that "this corollary has been so long and uniformly agreed to by the government and people of the United States that it may fairly be regarded as being now a part of the doctrine." The substance of the doctrine, according to this distinguished statesman, "is and always has been that the safety of the United States demands that America shall remain American."

The second policy associated with the Monroe Doctrine is the policy of establishing protectorates over the unstable countries in the region of the Caribbean, otherwise known as "Dollar Diplomacy." This has been discussed in a preceding chapter. The third policy intimately associated with the doctrine is that vague and indefinite policy known as the "Doctrine of Dominant or Paramount Interest" or the "United States Hegemony in the Americas." It found its most sweeping and bombastic utterance in the word of Secretary of State Olney who bravely declared that "Today the United States is practically sovereign on this continent, and its fiat is law upon the subjects to which it confines its interposition."

While these three aspects of our foreign policy may perhaps be denied any organic connection with the Monroe Doctrine, the fact remains that responsible statesmen in power and out of power have 


\section{The Monroe Doctrine of the Future 161}

sanctioned them as part and parcel of the doctrine, and the public at home and abroad have always so regarded them. In considering the criticism of the doctrine, and the demands for its abandonment or alteration, as a basis of determining its present and future status, these various aspects of the doctrine must be kept in mind.

Whether the Monroe Doctrine, as thus understopd, is to continue as the basis of the foreign policy of the future, will depend upon two factors: its usefulness to the United States, and our ability to enforce it. The latter subject has already been discussed. The value of the doctrine will be considered in connection with the five types of criticism, one or more of which seem to characterize the attitude of those who favor its abolition or alteration.

The first argument is that the Monroe Doctrine prevents the development of Central and South American countries, where there are great natural resources which can only be fully developed when their control passes to some European power. If the United States does not want to do it, we should at least permit European powers to establish colonies where law and order would be preserved and the natural resources developed for the world. Writing in 1905, Charles F. Dole gave sweeping expression to this argument. In urging the desirability of permitting Germany full liberty to colonize 
in South America he declared that,

Wherever they go, a higher civilization goes with them. Life and property are safer. A more efficient type of government is demanded. All this is surely for the interest of the United States. We can only be glad for any influences which will tone up the character of the South and Central American States. If they were all Germanized, the whole world, including the United States, would be permanently richer. In fact, the ties of trade and friendship between us and a possible Germanized state in South America would normally tend to be closer than they seem likely to be with the Spanish American peoples.

Obviously this argument is directed against the original doctrine itself and goes to its very fundamental principles. The United States has gone on the theory that her peace and safety was best secured by the continued independence of the Latin American states, and in addition that such a policy rendered useful service to her southern neighbors and to the cause of democracy. While the slow development of the capacity for self-government has been disappointing in some of these countries, the success in others has been reassuring. Further more, the colonial policies of some of the European nations do not give conclusive proof that thei colonization in this hemisphere would have been such a beneficent blessing to South America, to the United States, or to the world. 


\section{The Monroe Doctrine of the Future 103}

If there are those who, for one reason or another, demand that the administration of the more backward countries be placed in alien hands, the policy adopted should not be the Prussian doctrines of the superman, or that "might makes right," but hey should be taken over by the United States as the wards of civilization, under a mandate of a League of Nations. It is to be hoped that such an alternative will be avoided, but if inevitable it is only by such a policy that the problem can be handled without injury to the fundamental principles of international justice and law and to the security of free governments. For an effective system of international jurisprudence is essential to the peace and safety of the United States. This the World War has amply demonstrated. And yet had America abandoned the Monroe Doctrine in favor of European colonizacion, there can be little doubt that the unquestioned egal rights of Latin governments would have given way to the resistless power of European imperialism, and the effectiveness of international law thereby reduced.

Finally it is difficult to see why the European colonization of the Americas would not have vitally affected the possibilities of our foreign trade, a matter of rapidly increasing importance to the United States. As long as this territory is under the control of independent local governments we 
are able to compete on equal terms with European powers, but should the latter establish political dominion, in many cases American trade would be immediately confronted with the possibility of discriminating tariffs in favor of the colonizing power. It would appear, therefore, that even though the Monroe Doctrine may have prevented the most rapid exploitation of the natural resources of Latin America, that it has safeguarded the freedom and independence of the Latin states, helped to preserve the fundamental rules of international law, and secured to us equal opportunities in Latin American trade. In the accomplishment of these results the United States has an interest that is both obvious and vital.

The second criticism is that the Monroe Doctrine and its enforcement creates friction with Latin America, resulting in a growing hostility towards the United States and the disturbance of our commercial relations. The stronger Latin American states especially, it is said, resent such assertion of suzerainty over them as they feel is implied in recent aspects of the doctrine, especially those dealing with the protectorates in the Caribbean and the general assertion of a United States hegemony. They do not oppose the original doctrine nor the protection that it has afforded them, but they feel that the time has come when they should have a voice in its modern development and enforcement, 
The Monroe Doctrine of the Future 165

and when their general equality with the United States should be more fully recognized. They resented the Senate resolution over the Magdalena Bay episode as denying to their independent governments the full control over their own destiny, while the extravagant and undiplomatic assertions of Cleveland and Olney, although directed against European powers, gave needless grounds for offense. Moreover, the Panama incident and its bold defense by President Roosevelt were not calculated to calm their fears of the "Northern Peril."

There can be no doubt that these various assertions of our foreign policy have aroused suspicion and even hatred in some quarters and that many Latin American statesmen actually fear that their safety is menaced by American aggressiveness in the extension and enforcement of the doctrine. The almost unanimous opposition by Latin American countries to the recognition of the Monroe Doctrine in the covenant of the League of Nations affords ample evidence of this feeling. Nor can there be any doubt that such a state of public opinion among our southern neighbors makes for unfriendly feeling and discourages closer commercial ties.

The remedy for these conditions, however, need not be the abandonment of the policy, but more tactfulness in its assertion, a more studious and genuine regard for the rights, feelings, and interests 
of our neighbors, and a little less of "shirt sleeve" diplomacy and of American self-complacency. There is nothing inherent in the later aspects of the Monroe Doctrine that should necessarily cause friction if the matter is properly approached. Certainly Latin America would find only comfort and assurance in the enforcement of the doctrine by Cleveland in the Venezuelan case were it not for the offensive braggadocio that characterized its utterance.

Our opposition to the peaceful transfer of American territory to foreign powers is a reasonable means of safeguarding America against the kind of European quarrels that have arisen over affairs in Africa and Asia, and one which every American power (except the one desiring to make the cession) could be induced to accept as a part of sound PanAmerican policy, should the matter be approached in the spirit of cooperation rather than of arbitrary power. The same may be said of our policy of protectorates. We need not abandon our liberty of action, but need only to seek the cooperation and sympathetic understanding of the Latin powers, and to recognize their interest in the matter, to accomplish our ends without friction or misunderstanding in the great majority of cases. While it may be necessary for us to asșert a policy of dominant interest in this hemisphere as against European powers, especially in matters pertaining to the 


\section{The Monroe Doctrine of the Future 167}

Panama Canal, any assumption of an American hegemony or of a superior power over the rightful destinies of Latin states, cannot serve any useful purpose and will lead only to hostility and friction. To protect our legitimate rights under international law, by reasonable and proper means, is one thing, while to assume to make our fiat law in this hemisphere is a vastly different thing. And yet the press and public men of our nation have not failed to give just grounds for fear and distrust to our sister republics.

In the words of Elihu Root:

A false conception of what the Monroe Doctrine is, of what it demands and what it justifies, of its scope and of its limits, has invaded the public press and affected public opinion within the past few years. Grandiose schemes of national expansion invoke the Monroe Doctrine. Interested motives to compel Central or South American countries to do or refrain from doing something by which individual Americans may profit invoke the Monroe Doctrine. Clamors for national glory from minds too shallow to grasp at the same time a sense of national duty invoke the Monroe Doctrine. The intolerance which demands that control over the conduct and the opinions of other peoples which is the essence of tyranny invokes the Monroe Doctrine. Thoughtless people who see no difference between lawful right and physical power assume that the Monroe Doctrine is a warrant for interference in the internal affairs of all weaker nations in the New World. Against this supposititious doctrine many protests both in the United States and in South 
America have been made, and justly made. To the real Monroe Doctrine these protests have no application.

When, as secretary of state, Mr. Root visited South America and explained, with tactfulness and candor, the real attitude of the United States, the popular demonstration that he received and the increased friendliness for us which followed his visit, seemed to indicate that the cause of friction was not the content of our foreign policy but rather the unfortunate manner in which we have occasionally asserted it and the blatant, superior, and dictatorial attitude too frequently shown to the smaller Latin American republics by our press and public men. In speaking before the third PanAmerican , Conference at Rio Janeiro, Mr. Root summed up the attitude of the United States towards Latin America in these eloquent words:

We wish for no victories except those of peace; for no territory except our own; for no sovereignty except the sovereignty over ourselves. We deem the independence and equal rights of the smallest and weakest member of the family of nations entitled to as much respect as those of the greatest empire. We neither claim nor desire any rights, or privileges, or powers that we do not freely concede to every American republic.

These sentiments were supplemented by the words of President Wilson in his Mobile address, I9r3. 
The United States will never seek one additional foot of territory by conquest. . . . The future is going to be very different for this hemisphere from the past. These states lying to the south of us, which have always been our neighbors, will now be drawn closer to us by innumerable ties, and I hope, chief of all, by the tie of common understanding of each other, It is a spiritual union which we seek.

Perhaps no man in the United States is better qualified to discuss the Latin American point of view towards the Monroe Doctrine than John Barrett, Director General of the Pan-American Union. $\mathrm{He}$ believes that it is the various interpretations given to the doctrine and the patronizing or dictatorial air so frequently accompanying it, and not the principle of the Monroe Doctrine that gives offense.

If its haphazard interpretation can be supplanted with responsible and reasonable judgment, the majority of arguments against the doctrine in Latin America, and also in the United States, in describing it as obsolete will fail absolutely in their purpose and logic.

It thus appears that there is nothing inherently inimical between the Latin American republics and the original Monroe Doctrine or its two later aspects regarding the cession of American territory to foreign powers and the policy of protectorates in the Caribbean. The friction that is aroused is due to no clash of vital interests, but to the unnecessary 
and tactless assertion of an American hegemony by the United States, and the spirit of bravado and imperialism that has occasionally characterized our public utterances. Closer Pan-American relations are not to be secured by the abandonment of the Monroe Doctrine, therefore, but by a closer cooperation and more friendly understanding among American powers. The Monroe Doctrine, rightly understood, may thus become the real foundation of that genuine Pan-Americanism to which all American statesmen have aspired.

The third objection to the Monroe Doctrine is the objection to its name alone. The advocates of this objection do not quarrel necessarily with the principles of the doctrine, but since its name has been identified with many ideas and misconceptions which have aroused friction and abetted misunderstanding, they argue that the name should be abandoned. Many of the attacks upon the doctrine, when nicely analyzed, are not directed against the real principles involved so much as against certain misconceptions that have become identified with it. The evil effects of the name are illustrated in the following passage from John Barrett, although he doubtless had other matters in mind than the mere change of name.

By eliminating the attitude of absolute dictation and centralized power, which the Monroe Doctrine has been interpreted in Latin America as applying to the 
relations of the nations of the Western Hemisphere, by the substitution of "Pan-American" for "Monroe" - thus including all the American nations as sponsors - and by the substitution of "policy" for "doctrine" and thus removing the hard, unyielding, dictatorial and didactic suggestion of the words "Monroe Doctrine," about which every Latin American is a little sensitive, a long step will be taken towards a new era of PanAmerican comity and Pan-American confidence.

There seems to be no doubt that the words "Monroe Doctrine" carry with them certain unfortunate connotations and that as a term for the popular expression of our foreign policy it confuses rather than clarifies. A mere change of name will accomplish little, however, unless accompanied with a corresponding change in attitude, sympathy, and understanding towards Pan-American affairs, and a more intelligent interest in foreign politics among our people. In any event, though the name may change, the fundamental principles for which it really stands will remain and with them the fundamental problem of their tactful and statesman-like assertion in such a way as to safeguard American interests and at the same time to provide the basis for unity rather than disunity in Pan-American affairs.

The fourth argument against the Monroe Doctrine is that it endangers our peace and safety by bringing us into possible conflict with foreign powers. It is argued that it may be to the interest 
of some power to violate the doctrine, in which event we would be placed in the dilemma of having to abandon our position under fire or resort to arms in its defense. That the doctrine may lead to such serious alternatives no one will deny. But the vital question is whether it is not easier to defend the Monroe Doctrine than to meet the problems that would follow its abandonment. Is it not easier and safer to prevent foreign powers from acquiring strongholds in this hemisphere, than to defend ourselves against them when once established at our threshold? Would it not be easier to prevent a European state from acquiring territory adjacent to the Panama Canal than to defend the canal against such a power when once entrenched on the neighboring soil?

In a world where war is tolerated, every nation with wealth and colonies, which is contending for a portion of the world's commerce, must face the possibilities of war, and must therefore plan unceasingly for the national defense. The Monroe Doctrine has been adopted and observed because of the belief that the establishment of political dominion in this hemisphere by powerful foreign nations would make our own country more difficult to defend. We have been spared the burden of excessive armaments because of the absence of powerful military neighbors. This advantage ought to be maintained. 
The Monroe Doctrine of the Future 173

Moreover it is impossible to conceive of the American continents being thrown open to European politics and colonization without the danger of wars which would very materially threaten our national security. Controversies over Africa, the Far East, and the Balkans give us some idea of what the Monroe Doctrine has saved America.

To those who oppose the Monroe Doctrine because, in the last analysis, its vitality rests on force, former President Taft makes a telling reply.

Our constant upholding and assertion of the doctrine have enabled us, with the conflicting interests of European powers - the support of some and the acquiescence of others - to give effect to the doctrine for now nearly a century, and that without the firing of a single shot. This has secured the doctrine a traditional weight that the assertion of a new policy by the United States never could have. It is a national asset, and, indeed, an asset of the highest value for those who would promote the peace of the world. The mere fact that the further successful maintenance of the Monroe Doctrine, in the improbable event that any European power shall deliberately violate it, will require the exercise of force upon our part is certainly not a reason for the most sincere advocate of peace to insist upon sacrificing its beneficent influence and prestige as an instrument of peace to prevent European intermeddling in this hemisphere which a century of successful insistence without actual use of force has given it. . . . .

Were we to abandon the doctrine and thus, in effect, notify the European governments that, so far 
as our remonstrance or interposition was concerned, they might take possession of Santo Domingo, of Haiti, or of any of the Central American republics, or of any South American republics that might be disturbed by revolution and that might give them some international excuse for intervention, it would be but a very short time before we would be forced into controversies that would be much more dangerous to the peace of this hemisphere than our continued assertion of the doctrine properly understood and limited.

These conclusions of the distinguished author; would be difficult to refute.

The fifth argument against the Monroe Doctrine is that it is obsolete, the conditions that called it forth, viz., the American plans of the European alliance, having long since disappeared. But it will scarcely be contended that there are no longer any motives for European interference in the Americas. We know only too well of the land hunger of foreign powers, and of the lure of special concessions and commercial monopoly in portions of Latin America which political dominion would confer. The German attitude towards the Monroe Doctrine and the German policy towards Brazil can leave little room for doubt.

As long as there are such motives for foreign colonization in America, there is ample justification for the Monroe Doctrine as a protection against the dangers that would follow. Should the United 


\section{The Monroe Doctrine of the Future 175}

States attempt to acquire islands in the Mediterranean, establish a foothold in the Balkans, or negotiate for the acquisition of one of the petty nations of Europe, we would be met by the most formidable and hostile opposition. Experience has taught the nations of the world that the interests of self-defense require them, as a matter of policy, to oppose the establishment of any new center of friction, the acquisition of a strategic point of ittack, or the interference with the established international equilibrium in their quarter of the globe.

The same considerations require our adherence to the Monroe Doctrine, if we are to profit by the experience of the world, in building a policy of national defense. As Mr. Root has observed:

The most common exercise of the right of self-protection outside of a state's own territory and in time of peace is the interposition of objection to the occupation of territory, of points of strategic military or maritime advantage, or to indirect accomplishment of this effect by dynastic arrangement. For example, the objection of England in I9I I to the occupation of a naval station by Germany on the Atlantic Coast of Morocco; the objection of the European powers generally to the vast force of Russia extending its territory to the Mediterranean; the revision of the Treaty of San Stefano by the Treaty of Berlin; the establishment of buffer states; the objection to the succession of a German prince to the throne of Spain; the many forms of the Eastern Question; the centuries of struggle to preserve the Balance of Power in Europe 
- all depend upon the very same principle which underlies the Monroe Doctrine; that is to say, upon the right of every sovereign state to protect itself by pre venting a condition of affairs in which it will be too late to protect itself.

When all the criticisms of the Monroe Doctrine have been examined we find that most of them will be met by more tactful and diplomatic method of its assertion, a scrupulous and sympathetic regard for the dignity and rights of Latin American republics, and the abandonment of the spirit and idea of the United States hegemony in Pan-American affairs. This latter doctrine of superiority, which many fee] is but a cloak for imperialistic designs, has rendered us no useful service but has awakened only suspicion and distrust. But the objections that are aimed at the original principles of the doctrine and its later aspects against the peaceful acquisition of American territory by foreign powers and in favo of benevolent protectorates over the turbulent and unstable peoples of the Caribbean, lack persuasive ness and force. In a war-governed world, considerations of national defense require our firm adherence to the fundamental principles - foun essential to the safety of all nations - of protectin ourselves against the acquisition of strategic point of attack by new and powerful neighbors, the localization of centers of friction in neighboring or ad jacent territory, or the establishment therein of 
commercial monopoly through the extension of political power.

These great national needs the Monroe Doctrine has splendidly fulfilled. Its enforcement may conceivably involve us in great and costly wars, but if so, it will only be to protect ourselves against later conflicts, otherwise more severe because fought from the vantage ground which the enforcement of the doctrine has denied to our future foes. The doctrine does not cause the fundamental conflicts in national interests that lead to war, but secures to America important strategic advantages should it become necessary to battle for our national defense. Should the League of Nations succeed in securing peace and security throughout the world, the Monroe Doctrine may then become absorbed in this larger policy, but so long as self-defense is left to the devices of individual nations, the Monroe Doctrine will continue as the established policy of the future. As America grapples with the new problems of international life, the doctrine may find new expression, it may be merged into a policy of PanAmerican defense, it may be challenged in new and unexpected quarters and receive novel and startling application, but it is difficult to doubt that its fundamental principles must prevail. This policy of self-defense must be the doctrine of the future. 




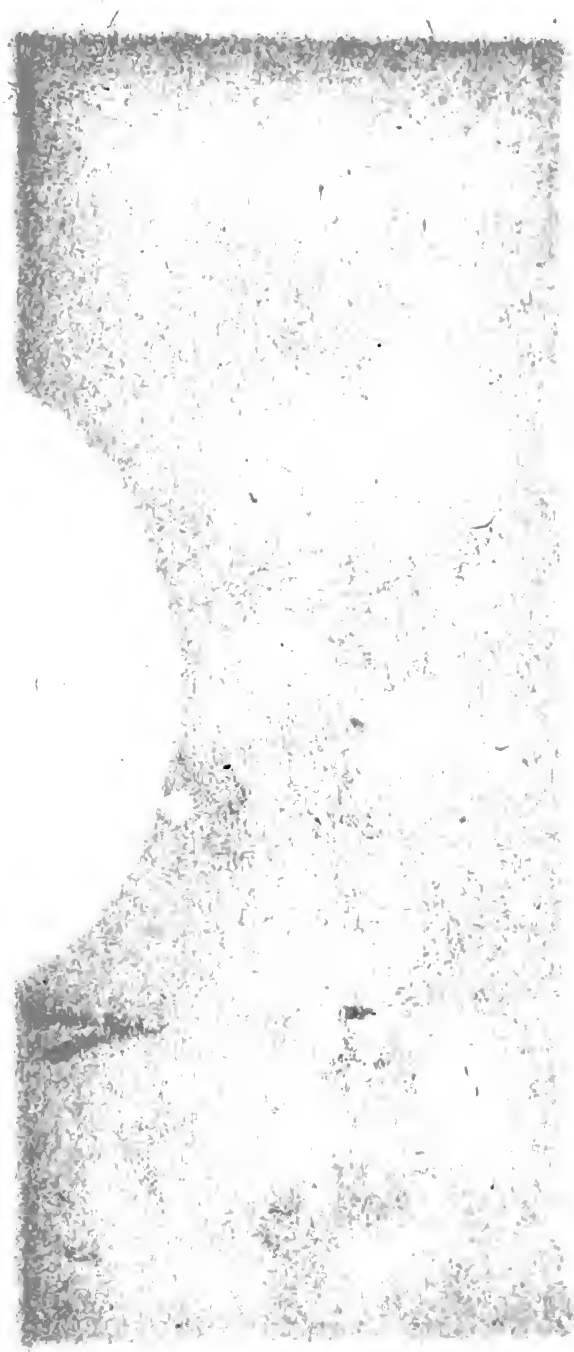

新

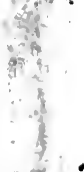




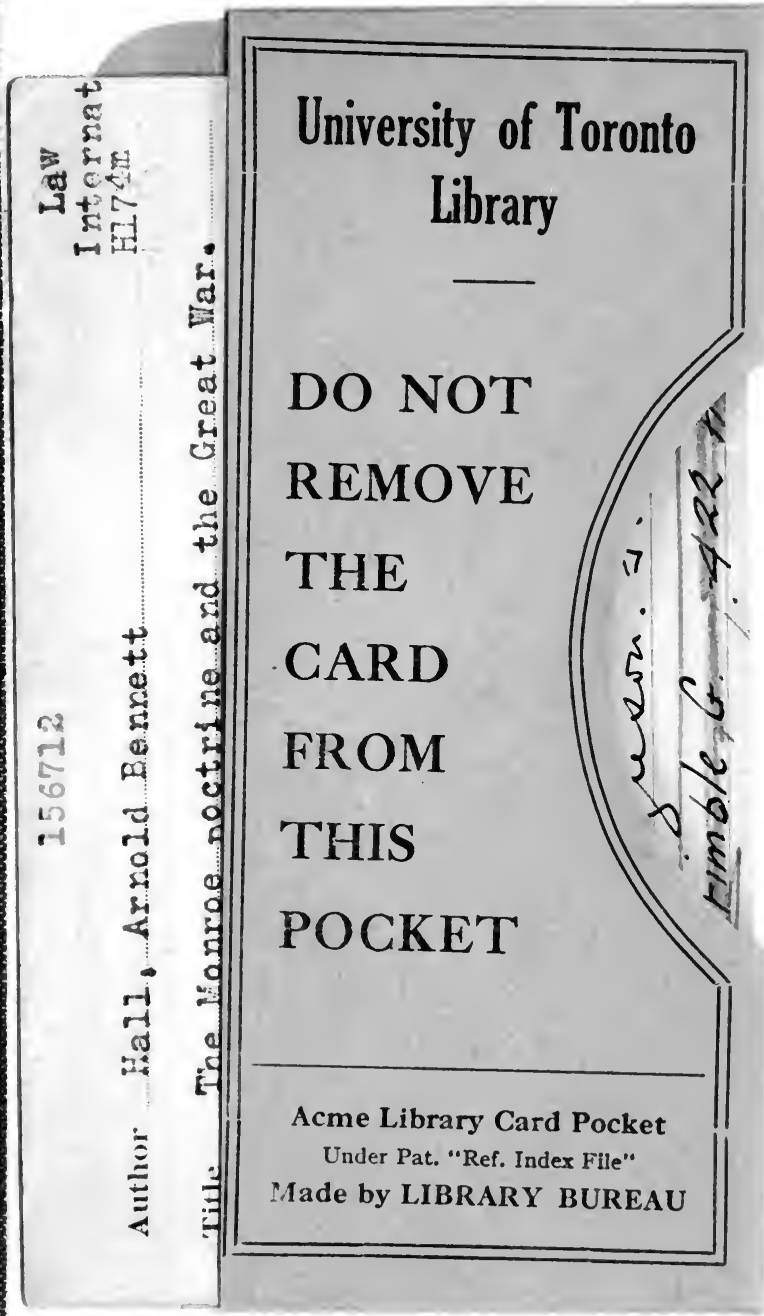


30.83

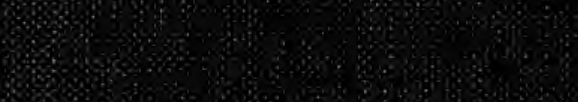

3.

(3)

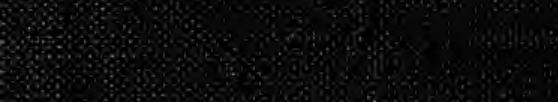

\%

\%

4.8.

\%

\%

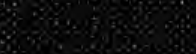

$8+50 \%$;

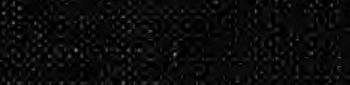

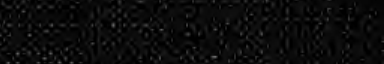

3.

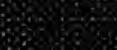

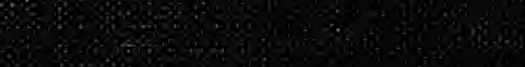

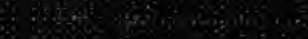

S.8.

\% 8

30 (1)

(2.)

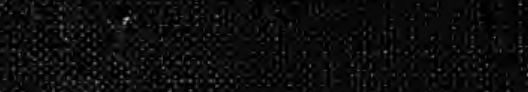

6. Hen:

(3)

4.5.

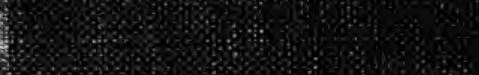

